NBER WORKING PAPER SERIES

\title{
EVIDENCE OF IMPROVED MONITORING AND INSOLVENCY RESOLUTION AFTER FDICIA
}

\author{
Edward J. Kane \\ Rosalind Bennett \\ Robert Oshinsky \\ Working Paper 14576
}

http://www.nber.org/papers/w14576

\author{
NATIONAL BUREAU OF ECONOMIC RESEARCH \\ 1050 Massachusetts Avenue \\ Cambridge, MA 02138 \\ December 2008
}

The views expressed herein are those of the author(s) and do not necessarily reflect the views of the National Bureau of Economic Research.

NBER working papers are circulated for discussion and comment purposes. They have not been peerreviewed or been subject to the review by the NBER Board of Directors that accompanies official NBER publications.

(C) 2008 by Edward J. Kane, Rosalind Bennett, and Robert Oshinsky. All rights reserved. Short sections of text, not to exceed two paragraphs, may be quoted without explicit permission provided that full credit, including $\odot$ notice, is given to the source. 
Evidence of Improved Monitoring and Insolvency Resolution after FDICIA

Edward J. Kane, Rosalind Bennett, and Robert Oshinsky

NBER Working Paper No. 14576

December 2008

JEL No. G21,G28,P51

\begin{abstract}
To realign supervisory and market incentives, the Federal Deposit Insurance Corporation Improvement Act of 1991 (FDICIA) adjusts two principal features of federal banking supervision. First, it requires regulators to examine insured institutions more frequently and makes them accountable for exercising their supervisory powers. Second, the Act empowers regulators to wind up the affairs of troubled institutions before their accounting net worth is exhausted.

Using 1984-2003 data on the outcome of individual bank examinations, this paper documents that the frequency of rating transitions and the character of insolvency resolutions have changed substantially under FDICIA. The average interval between bank examinations has dropped for low-rated banks in the post-FDICIA era. Examiner upgrades have become significantly more likely in the post-FDICIA era even after controlling for the state of the economy. However, in recessions managers are slower to correct problems that examiners identify. As a result, during downturns upgrades become less likely and absorptions become more likely.

Giving the FDIC authority to wind up troubled banks before their tangible net worth is exhausted has reduced the role of government in the insolvency-resolution process. Consistent with an hypothesis that FDICIA has improved incentives, our data show that a markedly larger percentage of troubled banks now search for a merger partner rather than trying to stay in business until the regulators force them to fail. This greater reliance on quasi-voluntary mergers is observable both within and across various stages of the business cycle. These findings suggest that supervisory interventions became more effective at banks during the post-FDICIA era.
\end{abstract}

Edward J. Kane

Department of Finance

Boston College

Chestnut Hill, MA 02467

and NBER

edward.kane@bc.edu

Rosalind Bennett

FDIC

Room 2097

55017 th Street

Washington, DC 20429

rbennett@fdic.gov

\author{
Robert Oshinsky \\ FDIC \\ 550 17th Street \\ Washington, DC 20429 \\ roshinsky@fdic.gov
}


In hopes of simultaneously improving supervisory and market incentives, the Federal Deposit Insurance Corporation Improvement Act of 1991 (FDICIA) expanded the authority and responsibilities of federal banking agencies in two ways. First, the Act requires regulators to exercise their monitoring and enforcement powers in a particular fashion. Second, the Act empowers regulators to wind up the affairs of troubled institutions before their accounting net worth is exhausted.

FDICIA formally requires regulators to conduct an on-site examination of every insured bank or thrift within specified intervals. It also requires them to initiate an escalating series of corrective actions and formal calls for the replenishment of capital when, and as, the capital position of an institution deteriorates. Finally, FDICIA makes the FDIC accountable for resolving failing institutions at minimum cost to the insurance fund. These obligations are enforced by requiring the Office of the Inspector General at the relevant agencies to file audit reports in cases that generate material losses to the deposit insurance fund. These reports review the timeliness and cost effectiveness of corrective actions taken (e.g., Office of Inspector General, 2003).

Two hypotheses underlie these changes. The first holds that accounting capital and examination ratings are at best lagging indicators of a bank's health, particularly when the economic environment in which it operates undergoes a major improvement or decline between reports. The second maintains that, prior to the enactment of FDICIA, incentives facing troubled depository institutions, and the agencies responsible for supervising them, perversely extended the lives of ruined firms (see, e.g., FDIC, 1997 or Kane, 1989). According to the second hypothesis, shortages of budgetary resources, which were in part politically driven, left authorities unable to examine banks frequently or carefully enough. Information gaps and delays 
intensified incentive conflicts. In turn, these incentive conflicts tempted supervisors to postpone the imposition of exit pressure. The result was that federal guarantees kept funds flowing to economically insolvent institutions long after private creditors would otherwise have forced them out of business.

This paper uses data from 1984 to 2005 on examination outcomes to test hypotheses about whether and how FDICIA influenced the timing and focus of the monitoring process and also the channels through which developing shortages of bank capital are treated and cured.

We want to stress that the influence of FDICIA and examination ratings on the path of bank and supervisory risk taking after 1991 was bound to be affected by other developments. In particular, large banks increasingly used securitizations and off-balance-sheet investment vehicles to mask their true leverage from bank examiners, while relaxed restrictions on interstate banking and branching increased the number of potential buyers for troubled banks. Changes in macroeconomic conditions should also affect the willingness and ability of bank managers to correct problems that examiners identify. In recessions, higher-rated institutions know that supervisors have to focus their resources on their most troubled clients and lack the time to exert much discipline on minor concerns.

Our paper seeks to test what we call the better-incentives hypothesis: the claim that, at least in the immediate wake of FDICIA, supervisory and failure resolution processes improved incentives for regulators and for bank shareholders, especially at banks that received low examination ratings.

Examinations can not register deteriorations or improvements in a bank's condition until some months after they occur. FDICIA encourages examiners to refocus their monitoring effort on positions, internal control systems, and strategies that expose the FDIC to loss. Our evidence 
shows a reduction in the average interval between completed examinations for low-rated banks. Substantial changes occur as well in the frequency and characteristics of rating transitions for all ratings classes.

Our findings also suggest that, at least for the risks that examiners could see, supervisory interventions became more effective at troubled banks. Rather than problem institutions transitioning into lower rating classes in successive exams and eventual failing, problem banks proved significantly more likely to recover. Furthermore, examiners prove significantly more likely to upgrade banks in successive examinations. The increased frequency of upgrades supports the hypothesis that problem banks faced stronger incentives to correct the particular deficiencies that examiners identify.

Still, common sense suggests that resolving supervisory concerns would require more effort as a bank's rating declines and also as the economic environment weakens. In line with this, post-FDICIA differences in ratings transitions prove more strongly significant both in business-cycle expansions than in recessions and for higher-rated institutions than for lowerrated ones.

Regulatory discipline includes: memoranda of understanding; cease-and-desist orders; removal, prohibition, or suspension of individuals; and notices of intent to terminate insurance (see Curry, O’Keefe, Coburn, and Montgomery, 1999; Office of Inspector General, 2003). Giving the FDIC responsibility and authority to wind up troubled banks before their tangible net worth disappears reduced the role that supervisory failures play in the insolvency-resolution process. Now, only banks in extreme distress find destabilizing “gambles for resurrection” an attractive strategy. As long as a troubled bank has substantial intangible franchise value to preserve, the prospect of prompt and strong regulatory discipline gives managers an incentive to 
rebuild their capital or to shop their enterprise to potential acquirers in and out of their headquarters state.

This paper develops statistical evidence that, aside from instances of sudden and severe distress, FDICIA enhanced regulatory and failing-bank incentives. The data show a marked increase both in examination frequency and in the percentages of problem banks that remedy their weaknesses or submit to a private takeover rather than waiting for regulators to pull their charter.

\section{Monitoring: Examiner Risk Assessments}

Managers of national safety nets are in the risk-acceptance and risk-management business. Conducting this business entails repeatedly monitoring client risk exposure, measuring and pricing it in a realistic manner, and taking timely steps to rein in excessive or inappropriate client risk-taking whenever it is observed (Kane, 1995 and Llewellyn and Mayes, 2003).

Using data from examinations conducted by Federal Reserve personnel, Hirtle and Lopez (1999, p. 2) estimate that data gathered in an on-site examination cease "to provide useful information about the current condition of a bank" somewhere between 18 months and three years after an examination. Between 1979 and 1986, the mean interval between successive onsite examinations at U.S. commercial banks surged from roughly a year to 609 days (FDIC, 1997, p. 429). Although the mean interval fell back thereafter, it did not fall to one year again until 1993. Of course, at many banks the interval between examinations would have been larger than the mean.

FDICIA now requires that "the appropriate Federal banking agency shall, not less than once during each 12-month period, conduct a full-scope, on-site examination of each insured depository institution.” However, FDICIA allows state examinations to be substituted for federal 
ones in alternating 12-month periods and expands the permissible interval to 18 months for most well-capitalized and well-managed institutions with less than $\$ 100$ million in total assets. Subsequently, for banks that receive high examination ratings on their last exam, the Community Development and Regulatory Improvement Act of 1994 increased the size threshold to \$250 million. In December 2006, the Financial Services Regulatory Relief Act increased the threshold again, this time to $\$ 500$ million.

Upon the completion of an exam, examiners assign each bank a composite grade between 1 and 5. The grade is based on a series of characteristics that together loosely estimate the risk that the bank poses to the deposit insurance fund. Banks rated 1 are held to be sound in every respect. Banks rated 2 are deemed fundamentally sound, while those rated 3 raise some degree of supervisory concern. Banks rated 4 and 5 exhibit unsafe and unsound practices or conditions.

On-site examination provides regulators with better information than they can obtain from merely monitoring financial institutions remotely. However, examiners' time is limited and they must employ tools of forensic accounting. The result is that examiners can only approximately rank the fragility and resiliency of individual banks. Still, other things equal, the higher the composite score, the worse the condition of the bank.

Traditionally, five characteristics were scored: capital, asset quality, management, earnings, and liquidity. These five component ratings were compiled into a single number called the composite "CAMEL" rating. However, opportunities for banks of all sizes to assume increasingly complex positions have expanded over time. This additional complexity was formally acknowledged in 1997, by adding a sixth component to the rating system—sensitivity to market risk (S). Furthermore, this revision to the bank rating system required bank 
supervisors to place more emphasis on evaluating risk management processes and practices at banks.

To strengthen the link between a bank’s rating history and the degree of supervisory pressure that it should experience, the prompt corrective-action (PCA) provisions of FDICIA rely on observable capital ratios. Over time, the deeper and more rapidly a bank's rating moves into adverse territory (ratings classes 3,4 , and 5), the more frequently and intensively that bank is apt to be re-examined and the more firmly it will be asked to address identified deficiencies (e.g., in asset quality or loss reserving) or to replenish its capital position. Presumably, the longer a bank languishes in a problem state, the higher the probability that banking authorities will decide to wrest control of its affairs from managers and shareholders.

Table 1 explores the proportion of insured institutions in each composite rating class that failed to experience a re-examination within each of three time intervals following a particular exam-12 months, 18 months and 24 months. ${ }^{1}$ Appendix A details the types of examinations included in our sample.

Table 1 divides the data into the two size categories by which 1994 legislation defined the maximum time span that should pass between exams. For each size category, the table compares exam frequency before and after the enactment of FDICIA. ${ }^{2}$

Within both size classes, the decline in the proportion of institutions that are not reexamined in the post-FDICIA period is striking and grows with the length of the interval. Differences in these distributions are statistically significant at conventional levels, except for the

\footnotetext{
${ }^{1}$ Because examination end dates are difficult to determine historically, we use start dates to determine the timing of the examinations. On the grounds that they merely extend the initial visit, examinations that occur within 30 days of the previous examination are not counted.

${ }^{2}$ We assume that examination timetables are fully compliant with FDICIA. The FDIC Examination Manual (FDIC, 2004) defines examination frequencies as the "the length of time between the end of one exam to the start of the next." Data limitations force us to measure examination frequency as the length of time between beginning dates of examinations. This will tend to overstate the interval between exams.
} 
poorest-rated category of small banks at the 24-month interval. ${ }^{3}$ The largest declines in the proportion of institutions that are not-reexamined occur for well-rated institutions. An institution can expand its loss exposures and dissipate its capital relatively more quickly today than in the past. Sponsors of FDICIA hoped that increasing examiner scrutiny would reinforce the discipline that private counterparties exert in derivatives, large-deposit, and subordinated-debt markets on troubled banks.

\section{Post-FDICIA Changes in Solvency-Enforcement Strategy}

Before running formal statistical tests comparing the pre- and post-FDICIA periods, it is important to explain how FDICIA changed the focus of the solvency-enforcement process. FDICIA seeks to overcome political and bureaucratic pressures that might unwisely delay the resolution of an economically insolvent institution. Procedures for implementing the Act focus on leverage ratios (ratios of bank capital to total assets) that are either calculated from data contained in bank Call Reports or established in transmittal reports prepared at the end of an examination. Typically, examiners identify a bank as a problem months before its accounting capital begins to deteriorate (Office of Inspector General, 2003).

Clever accounting can temporarily keep losses from registering on Call Reports. It often takes examiners more than a single examination cycle to uncover the full extent of ongoing patterns of loss concealment. By successfully under-reporting imbedded losses or underreserving for its loss exposures, an economically insolvent institution can avoid breaching PCA

\footnotetext{
${ }^{3}$ Throughout the paper we use four different tests to test for differences in the distributions: a t-test, an F-test, a Chi-squared test and a Kolgomorov-Smirnov (K-S) test. The null hypothesis for the t-test is that the probability in the subsample is equal to the probability in the whole sample. This test assumes that the probabilities are derived from a standard binomial distribution. We use an F-test to examine the null hypothesis that the variance in the subsample is the same as the variance for the whole sample. The null hypothesis for the Chi-squared test is that the row in each conditional, or subsample, probability matrix is drawn from the same population. Similarly, the null hypothesis for the K-S test is that two rows of the observed transition probabilities are drawn from the same population distribution. Results are available from the authors by request.
} 
thresholds or lessen the consequences of a particular breach by understating the needed injection of new capital (Office of the Inspector General, 2003). Because troubled banks so frequently under-reserve for loan losses, Berger, King, and O’Brien (1991) and Shibut, Critchfield, and Bohn (2003) suggest introducing a regression-based adjustment to each bank's reported loss reserves into PCA triggers. Such an adjustment could easily be extrapolated from Call Report data on delinquent and nonperforming loans. By drawing on recent and future advances in modeling credit risk, this approach could generate improved measures of the true quarterly net capital positions of problem banks.

Under the current system, institutions are classified as "undercapitalized” when their reported or examiner-adjusted capital (calculated as a percentage of bank assets) dips below any one of the thresholds shown in the third line of Table 2. Institutions that become "significantly undercapitalized” can be ordered to recapitalize promptly. However, to provide an opportunity for consultation, formal orders are preceded by a letter stating the regulatory agency's intent to issue a “PCA Directive”. The PCA Directive imposes specified proscriptions on the bank and requires its managers to file a satisfactory plan for restoring its capital to benchmarked levels within 60 days of the effective date of the Directive. In most cases, the institution has two weeks either to accept the Directive or to schedule an administrative hearing. When issued, the Directive notifies the bank that, if after 120 days it has not managed to increase the designated leverage ratios as required, it must immediately take "the necessary action" to find an acquirer or merger partner. Institutions whose tangible equity falls below two percent are deemed “critically undercapitalized.” PCA Directives sent to these firms have a shorter fuse and impose more proscriptions. 
FDICIA allows even strongly rated banks to be closed or taken over. Whenever serious accounting irregularities are discovered that, once corrected, cause the capital of the institution to drop below the "critically undercapitalized" threshold, the offending institution can be closed immediately. Accounting fraud and depositor runs can short-circuit PCA triggers. Losses to the deposit insurance fund in sudden failures (which dominate post-FDICIA failures) are very high.

Ordinarily, the failure process begins with the issuance of a "Failing Bank Letter" by the bank's chartering authority to the FDIC. To encourage competing bids, the FDIC markets the failing bank or thrift widely to potential acquirers. Although individual customers and speculators might sense the institution's growing weakness, its failing status is not revealed to the general public. FDIC personnel assemble an information package for potential bidders (FDIC, 1998, p. 6). Part of the information package is an asset-valuation review. Alternate resolution structures are studied and an on-site analysis is undertaken to prepare for the possible closing. A formal information meeting is held to discuss the details of the failing institution with the set of approved bidders. ${ }^{4}$ According to the FDIC, if the process results in a supervisory closure, it is "generally carried out in 90 to 100 days, not including the post-closing settlement timeframes” (FDIC, 1998, p. 76).

\section{Markov Transition Matrices: Preliminary Evidence}

This study seeks to infer how post-FDICIA examination and resolution protocols altered incentives for regulators and shareholders of banks in different CAMELS ratings classes. To do

\footnotetext{
${ }^{4}$ Potential acquirers submit bids in two parts: the first amount is the premium for the franchise value of the failed institution's deposits, and the second amount covers either all or whatever part of the institution's assets the bidder prefers. Bids are forwarded to FDIC headquarters, where they are compared and a least-cost determination is made.
} 
this, it studies rating transitions observed during 1984 to 2005 in completed exams across 12month, 18-month, and 24-month horizons. ${ }^{5}$

Our analysis investigates how transition frequencies vary when the data are partitioned in interesting ways. To compare any pair of matrices, we focus on their main diagonals and two principal subdiagonals. The subdiagonal immediately above the main diagonal (the "upper principal subdiagonal”) records the frequency of one-class downgrades. The subdiagonal immediately below the main diagonal (the "lower principal subdiagonal”) records the frequency of receiving a one-class upgrade.

Tables 3, 4, and 5 highlight differences in Markov transition matrices observed before and after FDICIA became effective in 1992. The rows of each matrix display the frequency distributions for transitions experienced by banks whose previous rating is indicated by the row label. To allow for all possibilities, the columns span not only each rating class, but also three absorbing states in which a bank formally ceases to exist ${ }^{6}$ and two other states that cover the possibility that a second examination did not begin during the horizon in question. Even though the data indicate that many banks with initial ratings of 1 to 4 did not experience the beginning of a new examination within a given time interval, the fraction of banks that were not re-examined in these classes declines noticeably after FDICIA.

For banks with more than $\$ 250$ million in assets ("large banks"), Table 3 displays the frequency distribution of one-year ratings transitions observed before and after FDICIA became effective in 1992. Although underlying transition probabilities are bound to vary over time with macroeconomic and industry conditions, these observed frequencies can be interpreted as estimates of average probabilities within each era. For completed exams at large banks, the odds

\footnotetext{
${ }^{5}$ If multiple examinations occur within the selected horizon, we record the rating given on the last exam.

${ }^{6}$ Disappearance can occur in either of three ways: a regulatory closure; a voluntary merger into an unconnected enterprise; or a "rollup" in which the bank is merged into a holding-company affiliate.
} 
of keeping the same rating in successive exams, is shown on the main diagonals. In both eras, it is unusual for a large bank to move up or down more than one class when it is re-examined. This is shown by the unshaded cells in the matrix. Kolmogorov-Smirnov and Chi-squared tests establish that, at better than one percent significance, every row of the pre-FDICIA matrix is different from the post-FDICIA matrix ${ }^{7}$

Three differences stand out from the table. First, the probability of receiving the same rating in the subsequent examination becomes significantly higher in the post-FDICIA era. Second, in part because the performance of both the economy and the banking industry was stronger after FDICIA than it had been before its passage, banks in the first four categories prove substantially more likely to be upgraded than in the past, as shown by the lower principal subdiagonals. Nevertheless, the likelihood of receiving a downgrade is more or less the same, as shown by the upper principal subdiagonals. Third, although the percentage of problem banks that are closed by the regulators approximately equals that of the pre-FDICIA period, the percentage of banks that consent to a voluntary merger is more than twice as high. We investigate later whether this effect may have been reinforced by the passage of the Interstate Banking and Branching Efficiency Act, which made interstate takeovers easier to solicit after 1994.

The increase in the frequency of one-step upgrades and voluntary mergers after FDICIA at large banks becomes more pronounced when we extend horizon for the transition matrices to a two-year horizon as shown in Table 4. Furthermore, one-step downgrades become notably less

\footnotetext{
${ }^{7}$ According to the K-S test, for each row, the null hypothesis that the observed transition probabilities in the preFDICIA period were drawn from the same population as those in the post-FDICIA era is rejected at one percent significance. According to the Chi-squared test, for each row, the null hypothesis that the pre-FDICIA transition probabilities are drawn from the same population as the post-FDICIA transition probabilities is also rejected at the one percent level.
} 
frequent after FDICIA. This may occur because the longer window allows for the completion of a large proportion of more challenging exams.

Similar patterns emerge for small banks using an 18-month observations window as shown in Table 5. In contrast to large banks, the odds of keeping the same rating are higher in the post-FDICIA period only for 1- and 2-rated banks. As in the case for large banks, upgrades become notably more common and downgrades become somewhat less frequent for all ratings transitions during the post-FDICIA era. Also, mergers provide a more frequent destination. Notably, for small banks over this longer horizon, the percentage of banks in the three lowestrated categories that have not been re-examined becomes very small in the post-FDICIA period.

Because banking problems are negatively correlated with national (and local) economic growth and positively correlated with sectoral volatility, variations in growth and volatility may exert an important influence on the transition probabilities. During the 1992 to 2005 era, these factors were favorable, so that the overall incidence of low-rated institutions declined. In the next section, we show that the increased reliance on quasi-voluntary mergers to resolve problem banks remains evident when pre-FDICIA and post-FDICIA data are segregated by proxies for the health of the national and local economic environments.

\section{Effects of National Economic Conditions on Ratings Transitions}

To disentangle the effects of differences due to national and local economic conditions from changes due to increased supervisory discipline after FDICIA, in this section and the next we reduce the dimensions of our analysis by consolidating the three absorbing states into a single state of "absorption" and eliminating post-period and not-rated observations. We do this because 
the resulting the $5 \times 5$ square transition matrices are less sensitive to horizon length and can be analyzed in powerful ways.

First we examine the transition matrices during recession periods and expansion periods at an 18-month interval for all insured institutions as shown in Table 6. The frequency of receiving the same rating is similar in recessions and expansion. The major differences occur in the probability of an upgrade along the lower partial subdiagonal and in the probability of absorption. During recessions, upgrades become less likely and absorptions more likely, but the frequency of downgrades rises only slightly. ${ }^{8}$

Next we contrast the transition matrices generated by splitting the pre- and post-FDICIA periods between observations that occurred during an expansion and during a recession, as shown in Tables 7 and 9. For both small and large banks, the probability of being upgraded rises after FDICIA during expansions and recessions alike. Although we illustrate only for the examination intervals that are most relevant to small and large banks, the same pattern emerges at other intervals. Results from Kolmogorov-Smirnov tests indicate that, in general, the differences in the transition matrices are more statistically significant along the pre- and postFDICIA dimension than along the expansion and recession dimension. This is shown in Tables 8 and 10. Furthermore, post-FDICIA differences are more strongly significant in expansions than in recessions and among higher-rated institutions. This supports the better-incentives hypothesis, because in these circumstances bank managers should find it less costly to respond to examiner criticisms.

\footnotetext{
${ }^{8}$ We should note that the table categorizes examination activity into business-cycle stage if both the beginning and ending examination occur within the same business-cycle stage. Because both recessions occurring during this period were only nine months long, much shorter than the length of the expansions, this definition results in an imbalance in the size of the subsamples-assigning ten times as many observations to expansions than to recessions. To investigate the effects of the imbalance, we also studied results for subsamples based only on whether the initial exam took place in a recession or expansion. The results were similar.
} 
To examine further the effects of the national economy on the transitions, we look at the ratings transitions from a survival analysis perspective. For each ratings class, Table 11 compares the mean and standard deviation of the number of months that elapse before a bank undergoes a ratings change or absorption before and after FDICIA. Within all five CAMELS classes, both the mean and the standard deviation of the number of months decline substantially. The same pattern emerges across ratings classes for small and large banks taken separately. The estimated empirical survival function is displayed in Figures 1 and 2. Treating expansion and recession periods separately, each curve plots the estimated probability that an institution stays in the same rating class against the number of months it has previously remained in that class. In both stages of the business cycle, the post-FDICIA survival functions begin above their pre-FDICIA counterparts and truncate sharply instead of developing a long tail. Consistent with the dictates of the Prompt Corrective Action provisions of FDICIA, postFDICIA survival functions truncate much earlier in recessions than in expansions. Irrespective of whether we apply a log-rank, Wilcoxon, or log-likelihood ratio (LLR) test, the differences between the pre- and post-FDICIA survival functions is significant at one percent.

Similar differences emerge when we construct survival functions along other dimensions. When we compare the survival function for pre-FDICIA to post-FDICIA for each size class, the curves differ significantly at one percent by all three tests for each business-cycle stage. If we then consider the survival function for each ratings class separately, differences are less strongly significant. The difference between pre- and post-FDICIA survival functions during expansion periods are significantly different at one percent according to the LLR test and at 5 percent or better according to the Wilcoxon test. In contrast, during recession periods, differences are never statistically significant for institutions rated CAMELS 1 and 5. For institutions rated CAMELS 
2 , 3, and 4, differences remain statistically significant at one percent for two of the three tests. The failure to find significant differences in the transition probabilities facing a 5-rated institution in recession implies that forbearance lives on and helps to explain delays in resolving zombie institutions like Indymac and Washington Mutual in 2007-08.

\section{Effects of Local Economic Growth on Ratings Transitions}

Conventional wisdom holds that small banks might be more sensitive to local economic growth than to national macroeconomic experience. This leads us to investigate whether and how pre-FDICIA and post-FDICIA ratings transitions differ when we control for local economic conditions.

To measure local economic conditions we chose to look at the growth of inflationadjusted personal income in an institution's headquarters state. We first calculated quarterly year-over-year growth rates for real personal income in each state over the 1984 to 2006 period. Within each state we partition the growth rates into quartiles. This variable indicates how strong growth in real personal income is in the current quarter is relative to growth over the entire time period. For example, growth in the first quartile (minimum to the $25^{\text {th }}$ percentile) would be representative of relatively weak growth, whereas growth in the fourth quartile $\left(75^{\text {th }}\right.$ to maximum growth) would be relatively strong growth. Finally, we matched each ratings transition with the quartile in which that bank's home-state growth rate lay in the quarter preceding the transitioning exam date.

When we control for local economic growth in this manner, our results generally hold. Tables 12 and 13 compare pre-FDICIA and post-FDICIA transition matrices using a one-year horizon for large banks and an 18-month horizon for small ones. In each quartile with few 
exceptions, the post-FDICIA era has seen upgrades become more likely, downgrades become less likely, and rates of absorption fall. Using a Kolmogorov-Smirnov test, the differences prove significant at five percent or better for 19 of 20 corresponding rows in the small-bank sample, but for only four rows in the large-bank sample. Interestingly, three of the significant large-bank differences are found in the most adverse situations. They relate to banks rated 3, 4, and 5 operating in the lowest growth quartile.

These results confirm the improved-incentives hypothesis for small banks across the board and for the critical class of poorly rated large banks facing difficult local circumstances.

\section{Voluntary Mergers and the Interstate Banking and Branching Efficiency Act}

As discussed above, the percentage of banks that consent to a voluntary merger is higher in the post-FDICIA period even after controlling for national and local economic conditions. One possible explanation for the increase in voluntary mergers is that the passage of the Interstate Banking and Branching Efficiency Act (IBBEA) made interstate takeovers easier to solicit after 1994. IBBEA authorizes adequately capitalized and well-managed bank holding companies to acquire banks in any state. Furthermore, the Act allows interstate mergers between adequately capitalized and well-managed banks beginning in June 1997.

To assess the impact of IBBEA, we investigate the extent to which roll-ups within a bank holding company and mergers with targets outside the holding company occurred in different states during the pre- and post-FDICIA period. If the IBBEA were driving the increase in the voluntary mergers, we would expect that out-of-state mergers would be the major form of mergers during the post-1994 period. Figures 3 and 4 show that in-state roll-ups and mergers dominate the number of voluntary mergers in all periods. Although the number of out-of-state 
mergers and roll-ups increased, the number of in-state mergers increased even more. This is

evidence that the increasing incidence of voluntary mergers is rooted in more than the IBBEA.

\section{$\underline{\text { 7. Differences in Transition Frequencies at Different Supervisory Agencies }}$}

Tables 14 through 17 investigate whether the transition matrices differ across the different regulators. Although four federal agencies share a responsibility for financial stability, their precise missions, supervisory clienteles, and incentive conflicts differ in important respects. The Federal Reserve's prime mission is to stabilize the macroeconomy and watch over the purchasing power of the dollar. Its special clientele consists of large financial holding companies and state-chartered member banks. The FDIC's mission is to resolve insolvent banks and thrifts and to protect the integrity of its deposit-insurance fund. Its special clientele includes nonmember state-chartered banks (“community banks”) and state banking supervisors. The Office of the Comptroller of the Currency (OCC) oversees the safety, soundness, and activities of national banks and their operating subsidiaries. Its special clientele may be described as money-center and regional banks. The Office of Thrift Supervision (OTS) supervises savings and loan associations, federal savings banks, and thrift holding companies. Realistically, its mission includes - and even stresses - the task of enhancing the availability of mortgage credit.

That significant differences emerge across agencies in the top two ratings classes and in the treatment of small institutions generally is shown in Tables 15 and 17. However, it should be noted that the sample contains many more observations for the FDIC than for the Federal Reserve, OCC, or OTS. Non-FDIC observations are unbalanced in time and by cycle stage as well. For example, at the 18-month interval for the Fed, our dataset records only 833 observations in pre-FDICIA expansions and 266 observations in pre-FDICIA recessions. The 
corresponding sample cells for the OCC contain only 587 and 157 observations respectively; OTS counts are larger: 1,915 and 791, respectively.

Table 18 shows that when we control only for business-cycle stage and the enactment of FDICIA, differences in the frequency distributions are significant at 5 percent or better for all 10 rows at the FDIC, and for 8 of the 10 rows at the OCC, but only for 3 out of the 10 rows at both the Fed and OTS. This is consistent with the hypothesis that their more-complex missions undercut supervisory incentives at the latter two agencies.

\section{Effects on the Sequencing of Rating Transitions}

Our final partition investigates the sequencing of upgrades and downgrades across successive examinations. For banks that receive a completed examination within the indicated intervals, Tables 19 and 20 show the conditional probabilities that apply pre-FDICIA and postFDICIA to large banks and small banks, respectively. In both tables, post-FDICIA changes in probabilities show identical patterns: (1) upgrades become less likely to follow upgrades; (2) upgrades become more likely to follow downgrades; and (3) downgrades become less likely to follow downgrades. These changes are statistically significant and further support the betterincentives hypothesis. The first pattern may be interpreted as a diminution of possible "halo" effects. The second and third show that banks that suffer downgrades are more promptly curing the deficiencies that an exam uncovers than they had in the past.

\section{Summary of Policy Implications}

O’Keefe and Dahl (1996) found that increases in examination frequency induced by FDICIA made CAMELS ratings more reliable indicators of bank condition. Data reviewed in 
this paper show that the character and quality of bank supervision in the United States also improved in the years following the enactment of FDICIA. During business-cycle expansions, our data strongly support the better-incentives hypothesis. Giving supervisors the authority and the obligation to wind up troubled banks before their accounting net worth can be exhausted helped to make banks respond more promptly to examiner criticism and to lessen the strength of go-for-broke incentives at troubled banks.

In 2007-08, FDICIA protocols have been tested by a deep and long-lasting macroeconomic slowdown. It turns out that the timeliness of regulators’ PCA triggers is weakened by relying on risk-weighted measures of capital adequacy and by accounting estimates of on-balance-sheet net worth rather than broader economic measures of bank capital. Nevertheless, during the post-FDICIA era, banks became more concerned with earning a favorable CAMELS rating than they had been previously. As opposed to making endgame gambles for resurrection or languishing in a problem state until regulators finally pull the plug, much larger proportions of problem banks did successfully rehabilitate themselves and preserved intangible value by searching out private takeover partners. 


\section{References}

Berger, Alan, Katherine King, and James O’Brien, 1991. The Limitations of Market-Value Accounting and a More Realistic Alternative. Journal of Banking and Finance 15, 753783.

Curry, Timothy J., John P. O’Keefe, Jane Coburn, and Lynne Montgomery, 1999. Financially Distressed Banks: How Effective Are Enforcement Actions in the Supervision Process? FDIC Banking Review 12, No. 2, 1-18.

Federal Deposit Insurance Corporation, 1998. Resolution Handbook: Methods for Resolving Troubled Institutions in the United States. Washington: FDIC.

, 2004. Risk Management Manual of Examination Policies. Division of Supervision and Consumer Protection. Washington: FDIC. December.

Hirtle, Beverly, and José A. Lopez, 1999. Supervisory Information and the Frequency of Bank Examinations. FRBNY Economic Policy Review April, 1-19.

Kane, Edward J., 1989. Changing Incentives Facing Financial-Services Regulators. Journal of Financial Services Research 2 (September), 265-274.

Kane, Edward J., 1995. Three Paradigms for the Role of Capitalization Requirements in Insured Financial Institutions. Journal of Banking and Finance 19 (June), 431-459.

Kaufman, George, and Robert Litan (Eds.), 1997. FDICIA: Bank Reform Five Years Later and Five Years Ahead. JAI Press.

Llewellyn, David T., and David G. Mayes, 2003. The Role of Market Discipline in Handling Problem Banks. Helsinki: Bank of Finland Discussion Paper No. 21/2003.

Office of Inspector General, Federal Deposit Insurance Corporation, 2003. The Role of Prompt Corrective Action as Part of the Enforcement Process. Audit Report No. 03-038 (September 12).

O’Keefe, John, and Drew Dahl, 1996. The Scheduling and Reliability of Bank Examinations: The Effect of FDICIA. Washington: FDIC (unpublished working paper).

Shibut, Lynn, Tim Critchfield, and Sarah Bohn, 2003. Differentiating Among Critically Undercapitalized Banks and Thrifts. FDIC Banking Review 15 (No. 2), 1-38. 
Appendix A

Types of Examinations Included in Source Data

\begin{tabular}{|c|c|c|c|c|c|c|c|}
\hline Description & $\begin{array}{c}\text { Years } \\
\text { Observed }\end{array}$ & \multicolumn{3}{|c|}{ Number of Examinations } & \multicolumn{3}{|c|}{ Percent of Examinations } \\
\hline Examination conducted by: & & Pre-FDICIA & Post-FDICIA & Total & Pre-FDICIA & Post-FDICIA & Total \\
\hline State Banking Authorities & 1984-2005 & 19,278 & 36,643 & 55,921 & 40.28 & 34.47 & 36.28 \\
\hline FDIC & 1984-2005 & 21,276 & 25,117 & 46,393 & 44.46 & 23.64 & 30.10 \\
\hline Federal Reserve or OCC & 1984-2005 & 398 & 25,843 & 26,241 & 0.84 & 24.32 & 17.02 \\
\hline OTS & 1989-2005 & 777 & 11,079 & 11,856 & 1.62 & 10.42 & 7.69 \\
\hline Joint Examinations & 1984-2005 & 2,753 & 5,253 & 8,006 & 5.75 & 4.94 & 5.19 \\
\hline Concurrent Examinations & 1984-1992 & 3,373 & 2,354 & 5,727 & 7.05 & 2.21 & 3.72 \\
\hline Total & & 47,855 & 106,289 & 154,144 & 100.00 & 100.00 & 100.00 \\
\hline
\end{tabular}


Table 1

Percentage of Institutions that Did Not Undergo a Complete Re-Examination

This table provides evidence on the percentage of large and small insured institutions in each composite rating class that did not undergo a complete re-

examination in the three indicated intervals before and after FDICIA. Small institutions are defined as institutions with less than \$250 million in assets. Large institutions are those with at least \$250 million in assets. The pre-FDICIA period is defined as 1984 to 1991 . The post-FDICIA period is defined as 1992 to 2003.

\begin{tabular}{|c|c|c|c|c|}
\hline \multicolumn{5}{|c|}{ Panel A: Large Institutions } \\
\hline \multicolumn{5}{|c|}{$\begin{array}{l}\text { Pre-FDICIA Period } \\
\end{array}$} \\
\hline Composite Rating & Number of Observations & Within 12 Months & Within 18 Months & Within 24 Months \\
\hline 1 & 421 & 82.19 & 59.62 & 43.23 \\
\hline 2 & 1,398 & 73.18 & 50.07 & 34.98 \\
\hline 3 & 553 & 67.81 & 34.36 & 22.78 \\
\hline 4 & 438 & 62.10 & 21.69 & 10.50 \\
\hline 5 & 318 & 50.94 & 16.67 & 6.29 \\
\hline \multicolumn{5}{|c|}{ Post-FDICIA Period } \\
\hline Composite Rating & Number of Observations & Within 12 Months & Within 18 Months & Within 24 Months \\
\hline 1 & 7,790 & 65.64 & 6.63 & 2.93 \\
\hline 2 & 9,537 & 64.28 & 7.52 & 3.45 \\
\hline 3 & 1,153 & 55.42 & 10.13 & 6.54 \\
\hline 4 & 488 & 45.49 & 13.46 & 7.52 \\
\hline 5 & 200 & 32.50 & 10.00 & 4.02 \\
\hline \multicolumn{5}{|c|}{ Panel B: Small Institutions } \\
\hline \multicolumn{5}{|c|}{$\begin{array}{l}\text { Pre-FDICIA Period } \\
\end{array}$} \\
\hline Composite Rating & Number of Observations & Within 12 Months & Within 18 Months & Within 24 Months \\
\hline 1 & 8,051 & 70.91 & 43.71 & 27.31 \\
\hline 2 & 20,659 & 69.45 & 42.52 & 26.55 \\
\hline 3 & 8,531 & 50.87 & 19.68 & 11.15 \\
\hline 4 & 5,562 & 44.77 & 12.69 & 6.20 \\
\hline 5 & 1,675 & 31.64 & 8.42 & 4.24 \\
\hline \multicolumn{5}{|c|}{ Post-FDICIA Period } \\
\hline Composite Rating & Number of Observations & Within 12 Months & Within 18 Months & Within 24 Months \\
\hline 1 & 28,290 & 78.39 & 35.98 & 7.68 \\
\hline 2 & 47,376 & 70.01 & 27.75 & 6.26 \\
\hline 3 & 8,547 & 43.62 & 7.52 & 4.68 \\
\hline 4 & 2,810 & 34.91 & 7.14 & 4.94 \\
\hline 5 & 657 & 25.39 & 6.58 & 4.81 \\
\hline
\end{tabular}


Table 2

\section{Prompt Corrective Action Categories}

The Prompt Correction Action categories are provided in the FDIC Rules and Regulations. To be considered well capitalized, an institution must not be subject to any formal enforcement action that requires it to meet and maintain a certain capital level. If the bank has a composite CAMELS rating of 1 in the most recent examination and is not experiencing or anticipating significant growth, then the leverage ratio can be as low as 3 percent for both the

Adequately Capitalized and Undercapitalized categories.

\begin{tabular}{|c|c|c|c|}
\hline & $\begin{array}{c}\text { Total Risk-Based } \\
\text { Capital Ratio }\end{array}$ & $\begin{array}{l}\text { Tier } 1 \text { Risk-Based } \\
\text { Capital Ratio }\end{array}$ & Leverage Ratio \\
\hline Well Capitalized & 10 percent or higher and & 6 percent or higher and & 5 percent or higher \\
\hline Adequately Capitalized & 10 percent or higher and & 4 percent or higher and & 4 percent or higher \\
\hline Undercapitalized & Less than 8 percent or & Less than 4 percent or & Less than 4 percent \\
\hline Significantly Undercapitalized & Less than 6 percent or & Less than 3 percent or & Less than 3 percent \\
\hline
\end{tabular}

Critically Undercapitalized 
Table 3

One-Year Transition Matrix for Large Institutions

This table provides the one-year transition matrix for composite examination ratings assigned in 1984 to 2003 to large FDIC-Insured institutions. The transition probabilities are expressed in percent. Large institutions are defined as those with at least $\$ 250$ million in total assets. The Pre-FDICIA period is defined as 1984 to 1991 and the post-FDICIA period is defined as 1992 to 2003. voluntary merger with an institution outside a bank's holding company. A roll-up is a merger between two entities within a holding company. "Post-period" refers to the case where the institution was rated within the time horizon but the time horizon did not expire until after the end of the period.

\begin{tabular}{|c|c|c|c|c|c|c|c|c|c|c|}
\hline \multicolumn{11}{|c|}{ Pre-FDICIA Period } \\
\hline & 1 & 2 & 3 & 4 & 5 & Failure & Merger & Roll-Up & $\begin{array}{c}\text { Not } \\
\text { Rated }\end{array}$ & $\begin{array}{c}\text { Post- } \\
\text { Period }\end{array}$ \\
\hline 1 & 12.59 & 2.38 & 0.00 & 0.00 & 0.00 & 0.00 & 0.71 & 0.48 & 82.19 & 1.66 \\
\hline 2 & 1.79 & 16.45 & 1.65 & 0.57 & 0.07 & 0.00 & 1.22 & 0.72 & 73.18 & 4.36 \\
\hline 3 & 0.00 & 4.88 & 14.47 & 2.71 & 0.72 & 0.00 & 1.81 & 1.08 & 67.81 & 6.51 \\
\hline 4 & 0.00 & 0.46 & 2.97 & 14.38 & 5.25 & 0.46 & 1.37 & 1.14 & 62.10 & 11.87 \\
\hline 5 & 0.00 & 0.00 & 0.94 & 2.83 & 9.12 & 23.27 & 1.57 & 1.26 & 50.94 & 10.06 \\
\hline \multicolumn{11}{|c|}{ Post-FDICIA Period } \\
\hline & 1 & 2 & 3 & 4 & 5 & Failure & Merger & Roll-Up & $\begin{array}{c}\text { Not } \\
\text { Rated }\end{array}$ & $\begin{array}{l}\text { Post- } \\
\text { Period }\end{array}$ \\
\hline 1 & 24.42 & 3.52 & 0.13 & 0.03 & 0.00 & 0.00 & 2.20 & 2.13 & 65.64 & 1.95 \\
\hline 2 & 3.62 & 23.31 & 1.05 & 0.20 & 0.03 & 0.01 & 2.67 & 2.28 & 64.28 & 2.56 \\
\hline 3 & 0.00 & 18.13 & 15.96 & 2.52 & 0.35 & 0.00 & 3.64 & 1.99 & 55.42 & 1.99 \\
\hline 4 & 0.00 & 3.48 & 16.19 & 23.16 & 5.12 & 0.61 & 3.69 & 2.05 & 45.49 & 0.20 \\
\hline 5 & 0.00 & 0.00 & 1.50 & 12.50 & 24.50 & 24.00 & 3.50 & 1.00 & 32.50 & 0.50 \\
\hline
\end{tabular}




\section{Table 4}

\section{Two-Year Transition Matrix for Large Institutions}

This table provides the two-year transition matrix for composite examination ratings assigned in 1984 to 2003 to large FDIC-Insured institutions. The transition probabilities are expressed in percent. Large institutions are defined as those with at least $\$ 250$ million in total assets. The Pre-FDICIA period is defined as 1984 to 1991 and the post-FDICIA period is defined as 1992 to 2003. "Merger” refers to a voluntary merger with an institution outside a bank's holding company. A roll-up is a merger between two entities within a holding company. "Post-period" refers to the case where the institution was rated within the time horizon but the time horizon did not expire until after the end of the period.

\begin{tabular}{|c|c|c|c|c|c|c|c|c|c|c|}
\hline \multicolumn{11}{|c|}{ Pre-FDICIA Period } \\
\hline & 1 & 2 & 3 & 4 & 5 & Failure & Merger & Roll-Up & $\begin{array}{c}\text { Not } \\
\text { Rated }\end{array}$ & $\begin{array}{c}\text { Post- } \\
\text { Period }\end{array}$ \\
\hline 1 & 31.35 & 12.83 & 0.24 & 0.71 & 0.00 & 0.00 & 2.38 & 0.95 & 43.23 & 8.31 \\
\hline 2 & 4.15 & 33.33 & 6.80 & 3.43 & 0.43 & 0.07 & 3.08 & 1.29 & 34.98 & 12.45 \\
\hline 3 & 0.18 & 15.01 & 25.14 & 10.31 & 3.80 & 0.54 & 3.44 & 1.27 & 22.78 & 17.54 \\
\hline 4 & 0.00 & 2.05 & 8.68 & 27.17 & 14.61 & 3.88 & 4.57 & 2.05 & 10.50 & 26.48 \\
\hline 5 & 0.00 & 0.94 & 3.77 & 6.29 & 16.98 & 36.79 & 2.52 & 2.20 & 6.29 & 24.21 \\
\hline \multicolumn{11}{|c|}{ Post-FDICIA Period } \\
\hline & 1 & 2 & 3 & 4 & 5 & Failure & Merger & Roll-Up & $\begin{array}{c}\text { Not } \\
\text { Rated }\end{array}$ & $\begin{array}{c}\text { Post- } \\
\text { Period }\end{array}$ \\
\hline 1 & 68.35 & 10.72 & 0.33 & 0.01 & 0.00 & 0.00 & 3.77 & 3.78 & 2.93 & 10.10 \\
\hline 2 & 12.21 & 61.43 & 2.64 & 0.41 & 0.08 & 0.02 & 4.72 & 4.03 & 3.45 & 11.00 \\
\hline 3 & 0.83 & 45.99 & 24.42 & 5.53 & 0.37 & 0.00 & 5.81 & 2.86 & 6.54 & 7.65 \\
\hline 4 & 0.63 & 15.66 & 31.32 & 24.01 & 6.89 & 1.04 & 6.68 & 3.76 & 7.52 & 2.51 \\
\hline 5 & 0.50 & 2.01 & 12.56 & 25.63 & 21.11 & 25.13 & 6.03 & 1.51 & 4.02 & 1.51 \\
\hline
\end{tabular}


Table 5

18-Month Transition Matrix for Small Institutions

This table provides the 18-month transition matrix for composite examination ratings assigned in 1984 to 2003 to small FDIC-Insured institutions. The transition probabilities are expressed in percent. Small institutions are defined as those with less than \$250 million in total assets. The Pre-FDICIA period is defined as 1984 to 1991 and the post-FDICIA period is defined as 1992 to 2003. to a voluntary merger with an institution outside a bank's holding company. A roll-up is a merger between two entities within a holding company. "Post-period" refers to the case where the institution was rated within the time horizon but the time horizon did not expire until after the end of the period.

\begin{tabular}{|c|c|c|c|c|c|c|c|c|c|c|}
\hline \multicolumn{11}{|c|}{ Pre-FDICIA Period } \\
\hline & 1 & 2 & 3 & 4 & 5 & Failure & Merger & Roll-Up & $\begin{array}{c}\text { Not } \\
\text { Rated }\end{array}$ & $\begin{array}{c}\text { Post- } \\
\text { Period } \\
\end{array}$ \\
\hline 1 & 35.93 & 10.53 & 0.56 & 0.11 & 0.00 & 0.04 & 1.55 & 0.68 & 43.71 & 6.88 \\
\hline 2 & 4.45 & 36.83 & 4.53 & 1.06 & 0.18 & 0.03 & 1.80 & 0.64 & 42.52 & 7.95 \\
\hline 3 & 0.21 & 24.65 & 33.90 & 8.77 & 0.81 & 0.23 & 1.92 & 0.68 & 19.68 & 9.14 \\
\hline 4 & 0.00 & 4.17 & 20.78 & 38.85 & 9.30 & 2.36 & 2.36 & 0.47 & 12.69 & 9.03 \\
\hline 5 & 0.00 & 0.72 & 3.04 & 11.58 & 29.19 & 32.24 & 3.88 & 0.90 & 8.42 & 10.03 \\
\hline \multicolumn{11}{|c|}{ Post-FDICIA Period } \\
\hline & 1 & 2 & 3 & 4 & 5 & Failure & Merger & Roll-Up & $\begin{array}{c}\text { Not } \\
\text { Rated }\end{array}$ & $\begin{array}{c}\text { Post- } \\
\text { Period }\end{array}$ \\
\hline 1 & 48.44 & 9.42 & 0.30 & 0.04 & 0.01 & 0.00 & 2.19 & 1.91 & 35.98 & 1.71 \\
\hline 2 & 8.95 & 51.95 & 3.20 & 0.44 & 0.06 & 0.03 & 2.34 & 1.72 & 27.75 & 3.56 \\
\hline 3 & 0.63 & 43.73 & 33.52 & 4.75 & 0.38 & 0.10 & 2.99 & 1.34 & 7.52 & 5.03 \\
\hline 4 & 0.07 & 13.05 & 35.23 & 28.31 & 5.52 & 0.61 & 5.73 & 1.48 & 7.14 & 2.85 \\
\hline 5 & 0.61 & 4.59 & 11.03 & 21.75 & 22.97 & 21.75 & 6.74 & 2.14 & 6.58 & 1.84 \\
\hline
\end{tabular}


Table 6

Transition Matrix for All FDIC-Insured Institutions During Business Cycle Periods

This table provides the 18-month transition matrix for composite examination ratings assigned in 1984 to 2003 to all FDIC-Insured institutions. The transition probabilities are expressed in percent. Recessions and expansions are defined by NBER business cycle peaks and troughs. Transitions are counted only for the transitions in which both end-points occur on the same side of an NBER-defined business-cycle peak or trough. Absorption includes failures, mergers within a bank holding company, and mergers with a bank outside the holding company.

\begin{tabular}{|c|c|c|c|c|c|c|c|c|}
\hline \multicolumn{9}{|c|}{ Recession Periods } \\
\hline & 1 & 2 & 3 & 4 & 5 & Absorption & Total & Number \\
\hline 1 & 72.76 & 16.06 & 0.53 & 0.11 & 0.00 & 10.54 & 100.00 & 2,647 \\
\hline 2 & 7.14 & 70.82 & 8.03 & 1.87 & 0.38 & 11.76 & 100.00 & 4,497 \\
\hline 3 & 0.09 & 30.07 & 47.10 & 9.63 & 1.53 & 11.58 & 100.00 & 1,174 \\
\hline 4 & 0.34 & 3.21 & 22.17 & 50.08 & 10.15 & 14.04 & 100.00 & 591 \\
\hline 5 & 0.00 & 0.44 & 1.31 & 11.35 & 35.37 & 51.53 & 100.00 & 229 \\
\hline \multicolumn{9}{|c|}{ Expansion Periods } \\
\hline & 1 & 2 & 3 & 4 & 5 & Absorption & Total & Number \\
\hline 1 & 77.07 & 15.36 & 0.55 & 0.08 & 0.01 & 6.93 & 100.00 & 27,637 \\
\hline 2 & 12.26 & 74.48 & 5.54 & 0.99 & 0.15 & 6.58 & 100.00 & 49,381 \\
\hline 3 & 0.45 & 43.48 & 41.70 & 8.39 & 0.87 & 5.21 & 100.00 & 13,571 \\
\hline 4 & 0.04 & 8.21 & 31.46 & 42.42 & 9.81 & 8.06 & 100.00 & 6,994 \\
\hline 5 & 0.14 & 1.91 & 6.34 & 17.77 & 31.25 & 42.58 & 100.00 & 2,144 \\
\hline
\end{tabular}


Table 7

Transition Matrix for Small Institutions During Business Cycle Periods

This table provides the 18-month transition matrix for composite examination ratings assigned in 1984 to 2003 to small FDIC-Insured institutions. The transition probabilities are expressed in percent. Small institutions are defined as those with less than $\$ 250$ million in total assets. The Pre-FDICIA period is defined as 1984 to 1991 and the post-FDICIA period is defined as 1992 to 2003.

expansion periods are defined by NBER business-cycle peaks and troughs. Absorption includes failures, mergers within a bank holding company, and mergers with a bank outside the holding company

\begin{tabular}{|c|c|c|c|c|c|c|c|}
\hline \multicolumn{8}{|c|}{ Pre-FDICIA Expansion Period } \\
\hline & 1 & 2 & 3 & 4 & 5 & Absorption & Total \\
\hline 1 & 72.44 & 21.86 & 1.27 & 0.25 & 0.04 & 4.15 & 100.00 \\
\hline 2 & 10.30 & 73.39 & 9.12 & 2.21 & 0.38 & 4.60 & 100.00 \\
\hline 3 & 0.36 & 34.70 & 48.03 & 11.90 & 1.06 & 3.95 & 100.00 \\
\hline 4 & 0.00 & 5.30 & 26.60 & 50.59 & 11.09 & 6.43 & 100.00 \\
\hline 5 & 0.00 & 1.18 & 3.74 & 15.39 & 36.32 & 43.36 & 100.00 \\
\hline \multicolumn{8}{|c|}{ Post-FDICIA Expansion Period } \\
\hline & 1 & 2 & 3 & 4 & 5 & Absorption & Total \\
\hline 1 & 77.69 & 15.45 & 0.49 & 0.07 & 0.02 & 6.28 & 100.00 \\
\hline 2 & 12.84 & 75.83 & 4.82 & 0.68 & 0.09 & 5.74 & 100.00 \\
\hline 3 & 0.71 & 49.76 & 38.65 & 5.38 & 0.44 & 5.05 & 100.00 \\
\hline 4 & 0.08 & 14.71 & 38.99 & 31.44 & 6.04 & 8.74 & 100.00 \\
\hline 5 & 0.67 & 5.18 & 12.02 & 23.71 & 25.04 & 33.39 & 100.00 \\
\hline \multicolumn{8}{|c|}{ Pre-FDICIA Recession Period } \\
\hline & 1 & 2 & 3 & 4 & 5 & Absorption & Total \\
\hline 1 & 69.49 & 23.19 & 1.63 & 0.31 & 0.08 & 5.29 & 100.00 \\
\hline 2 & 9.44 & 70.01 & 11.00 & 3.24 & 0.69 & 5.62 & 100.00 \\
\hline 3 & 0.20 & 29.41 & 53.36 & 10.98 & 0.60 & 5.46 & 100.00 \\
\hline 4 & 0.10 & 4.03 & 25.78 & 54.18 & 9.67 & 6.24 & 100.00 \\
\hline 5 & 0.00 & 1.32 & 1.85 & 15.61 & 38.36 & 42.86 & 100.00 \\
\hline \multicolumn{8}{|c|}{ Post-FDICIA Recession Period } \\
\hline & 1 & 2 & 3 & 4 & 5 & Absorption & Total \\
\hline 1 & 77.83 & 17.42 & 0.51 & 0.09 & 0.03 & 4.12 & 100.00 \\
\hline 2 & 8.92 & 79.20 & 6.93 & 0.92 & 0.06 & 3.97 & 100.00 \\
\hline 3 & 0.00 & 38.82 & 46.11 & 9.17 & 0.88 & 5.03 & 100.00 \\
\hline 4 & 0.65 & 6.54 & 39.87 & 35.29 & 6.54 & 11.11 & 100.00 \\
\hline 5 & 0.00 & 0.00 & 11.11 & 44.44 & 27.78 & 16.67 & 100.00 \\
\hline
\end{tabular}


Table 8

Kolmogorov-Smirnov Test Results

Transition Matrix for Small Institutions During Business Cycle Periods

This table provides the results of Kolmogorov-Smirnov (K-S) tests applied to the 18-month transition matrix for the composite examination ratings assigned in 1984 to 2003 to small FDIC-Insurred Institutions. Small institutions are those with less than \$250 million in total assets. The Pre-FDICIA period is defined as 1984 to 1991 and the post-FDICIA period as 1992 to 2003. Recession and expansion periods are determined by the NBER business-cycle peaks and troughs. The null hypothesis for the K-S test is that the row probabilities for the two groups are drawn from the same distribution.

$*=$ Can reject the null hypothesis at the $90 \%$ confidence level, $* *=95 \%$, $* * *=99 \%$

\begin{tabular}{|c|c|c|c|}
\hline \multicolumn{2}{|c|}{ Pre-FDICIA Expansion vs. Post-FDICIA Expansion } & \multicolumn{2}{|c|}{ Pre-FDICIA Recession vs. Post-FDICIA Recession } \\
\hline 1 & $* * *$ & 1 & $* * *$ \\
\hline & $* * *$ & 2 & $* * *$ \\
\hline 3 & $* * *$ & 3 & $* * *$ \\
\hline 4 & $* * *$ & 4 & $* * *$ \\
\hline 5 & $* * *$ & 5 & $* *$ \\
\hline \multicolumn{2}{|c|}{ Pre-FDICIA Expansion vs. Pre-FDICIA Recession } & \multicolumn{2}{|c|}{ Post-FDICIA Expansion vs. Post-FDICIA Recession } \\
\hline 1 & & 1 & \\
\hline & $* * *$ & 2 & $* * *$ \\
\hline 3 & $* * *$ & 3 & $* * *$ \\
\hline 4 & & 4 & \\
\hline 5 & & 5 & \\
\hline
\end{tabular}


Table 9

Transition Matrix for Large Institutions During Business Cycle Periods

This table provides the one-year transition matrix for composite examination ratings assigned in 1984 to 2003 to large FDIC-Insured institutions. The transition probabilities are expressed in percent. Large institutions are defined as those with at least \$250 million in total assets. The Pre-FDICIA period is defined as 1984 to 1991 and the post-FDICIA period is defined as 1992 to 2003 . Recession and expansion periods are defined by NBER businesscycle peaks and troughs. Absorption includes failures, mergers within a bank holding company, and mergers with a bank outside the holding company

\begin{tabular}{|c|c|c|c|c|c|c|c|}
\hline \multicolumn{8}{|c|}{ Pre-FDICIA Expansion Period } \\
\hline & 1 & 2 & 3 & 4 & 5 & Absorption & Total \\
\hline 1 & 61.54 & 22.22 & 2.56 & 0.85 & 0.00 & 12.82 & 100.00 \\
\hline 2 & 7.60 & 67.30 & 10.84 & 5.13 & 0.95 & 8.17 & 100.00 \\
\hline 3 & 0.00 & 20.82 & 51.02 & 15.10 & 4.90 & 8.16 & 100.00 \\
\hline 4 & 0.00 & 2.41 & 18.47 & 51.00 & 18.47 & 9.64 & 100.00 \\
\hline 5 & 0.00 & 0.49 & 2.93 & 11.22 & 29.27 & 56.10 & 100.00 \\
\hline \multicolumn{8}{|c|}{ Post-FDICIA Expansion Period } \\
\hline & 1 & 2 & 3 & 4 & 5 & Absorption & Total \\
\hline 1 & 76.20 & 11.59 & 0.39 & 0.07 & 0.00 & 11.75 & 100.00 \\
\hline 2 & 10.31 & 72.53 & 3.35 & 0.58 & 0.08 & 13.16 & 100.00 \\
\hline 3 & 0.00 & 42.27 & 37.80 & 6.52 & 0.74 & 12.66 & 100.00 \\
\hline 4 & 0.00 & 6.14 & 30.32 & 42.24 & 9.75 & 11.55 & 100.00 \\
\hline 5 & 0.00 & 0.00 & 2.21 & 19.12 & 36.76 & 41.91 & 100.00 \\
\hline \multicolumn{8}{|c|}{ Pre-FDICIA Recession Period } \\
\hline & 1 & 2 & 3 & 4 & 5 & Absorption & Total \\
\hline 1 & 40.74 & 25.93 & 0.00 & 7.41 & 0.00 & 25.93 & 100.00 \\
\hline 2 & 3.42 & 55.48 & 23.97 & 10.27 & 0.68 & 6.16 & 100.00 \\
\hline 3 & 0.00 & 16.87 & 32.53 & 25.30 & 15.66 & 9.64 & 100.00 \\
\hline 4 & 0.00 & 1.05 & 9.47 & 52.63 & 26.32 & 10.53 & 100.00 \\
\hline 5 & 0.00 & 1.10 & 3.30 & 5.49 & 26.37 & 63.74 & 100.00 \\
\hline \multicolumn{8}{|c|}{ Post-FDICIA Recession Period } \\
\hline & 1 & 2 & 3 & 4 & 5 & Absorption & Total \\
\hline 1 & 80.81 & 13.41 & 0.22 & 0.00 & 0.00 & 5.56 & 100.00 \\
\hline 2 & 7.79 & 81.02 & 3.90 & 0.50 & 0.10 & 6.69 & 100.00 \\
\hline 3 & 0.00 & 41.18 & 40.00 & 8.24 & 2.35 & 8.24 & 100.00 \\
\hline 4 & 0.00 & 5.56 & 16.67 & 33.33 & 27.78 & 16.67 & 100.00 \\
\hline 5 & 0.00 & 0.00 & 0.00 & 0.00 & 0.00 & 100.00 & 100.00 \\
\hline
\end{tabular}


Table 10

Kolmogorov-Smirnov Test Results

Transition Matrix for Large Institutions During Business Cycle Periods

This table provides the results of Kolmogorov-Smirnov (K-S) tests applied to the one-year transition matrix for the composite examination ratings assigned in 1984 to 2003 to large FDIC-Insured Institutions. Large institutions are those with at least \$250 million in total assets. The Pre-FDICIA period is defined as 1984 to 1991 and the post-FDICIA period as 1992 to 2003. Recession and expansion periods are determined by the NBER business-cycle peaks and troughs. The null hypothesis for the K-S test is that the row probabilities for the two groups are drawn from the same distribution.

$*=$ Can reject the null hypothesis at the $90 \%$ confidence level, $* *=95 \%, * * *=99 \%$

\begin{tabular}{|c|c|c|c|}
\hline \multicolumn{2}{|c|}{ Pre-FDICIA Expansion vs. Post-FDICIA Expansion } & \multicolumn{2}{|c|}{ Pre-FDICIA Recession vs. Post-FDICIA Recession } \\
\hline 1 & $* *$ & 1 & $* * *$ \\
\hline 2 & $* * *$ & 2 & $* * *$ \\
\hline 3 & $* * *$ & 3 & $* * *$ \\
\hline 4 & $* * *$ & 4 & \\
\hline 5 & $*$ & 5 & \\
\hline \multicolumn{2}{|c|}{ Pre-FDICIA Expansion vs. Pre-FDICIA Recession } & \multicolumn{2}{|c|}{ Post-FDICIA Expansion vs. Post-FDICIA Recession } \\
\hline 1 & & 1 & $* * *$ \\
\hline 2 & $* * *$ & 2 & $* * *$ \\
\hline 3 & $* * *$ & 3 & \\
\hline 4 & & 4 & \\
\hline 5 & & 5 & \\
\hline
\end{tabular}


Table 11

Number of Months until FDIC-Insured Banks Undergo a Change in State

This table provides the number of until FDIC-Insured Banks undergo a change in state which is defined as either a ratings change or absorption. Absorption includes failures, mergers within a bank holding company, and mergers with a bank outside the holding company. The results are presented by CAMELS rating class. The Pre-FDICIA Period is defined as 1984 to 1991 and the post-FDICIA period is defined as 1992 to 2003.

\begin{tabular}{|c|c|c|c|c|c|c|c|c|c|c|}
\hline & \multicolumn{2}{|c|}{1} & \multicolumn{2}{|c|}{2} & \multicolumn{2}{|c|}{3} & \multicolumn{2}{|c|}{4} & \multicolumn{2}{|c|}{5} \\
\hline & $\begin{array}{c}\text { Pre- } \\
\text { FDICIA }\end{array}$ & $\begin{array}{c}\text { Post- } \\
\text { FDICIA }\end{array}$ & $\begin{array}{c}\text { Pre- } \\
\text { FDICIA }\end{array}$ & $\begin{array}{c}\text { Post- } \\
\text { FDICIA }\end{array}$ & $\begin{array}{c}\text { Pre- } \\
\text { FDICIA }\end{array}$ & $\begin{array}{c}\text { Post- } \\
\text { FDICIA }\end{array}$ & $\begin{array}{c}\text { Pre- } \\
\text { FDICIA }\end{array}$ & $\begin{array}{c}\text { Post- } \\
\text { FDICIA }\end{array}$ & $\begin{array}{c}\text { Pre- } \\
\text { FDICIA }\end{array}$ & $\begin{array}{c}\text { Post- } \\
\text { FDICIA }\end{array}$ \\
\hline Mean & 75.40 & 51.21 & 65.38 & 45.58 & 28.22 & 19.71 & 26.39 & 19.13 & 19.31 & 15.96 \\
\hline $\begin{array}{l}\text { Standard } \\
\text { Deviation }\end{array}$ & 67.85 & 40.42 & 52.61 & 36.18 & 22.74 & 15.19 & 19.48 & 16.03 & 24.15 & 16.51 \\
\hline $\begin{array}{l}\text { Number of } \\
\text { Observations }\end{array}$ & 3,624 & 9,076 & 9,609 & 13,650 & 5,348 & 4,316 & 3,237 & 1,187 & 1,397 & 292 \\
\hline
\end{tabular}


Table 12

Transition Matrix for Large Institutions by Local Economic Conditions

This table provides the one-year transition matrix for composite examination ratings assigned in 1984 to 2003 to large FDIC-Insured institutions. The transition probabilities are expressed in percent. Large institutions are defined as those with at least \$250 million in total assets. The Pre-FDICIA period is defined as 1984 to 1991 and the post-FDICIA period is defined as 1992 to 2003. State income growth is the quarterly year-over-year growth in inflation adjusted personal

income in the state in which in the institution is headquartered. The growth rates are calculated over the 1984 to 2006 period and partitioned into quartiles. The first quartile of state personal income growth, representing the weakest growth, is the minimum to the $25^{\text {th }}$ percentile, the second quartile is the $25^{\text {th }}$ to the $50^{\text {th }}$, the third quartile is the $50^{\text {th }}$ to the $75^{\text {th }}$ percentile and the fourth quartile is the $75^{\text {th }}$ to the maximum, representing the strongest growth.

\begin{tabular}{|c|c|c|c|c|c|c|c|}
\hline \multicolumn{8}{|c|}{ Pre-FDICIA, First Quartile State Income Growth } \\
\hline & & 2 & 3 & 4 & 5 & Absorption & Total \\
\hline 1 & 69.23 & 15.38 & 0.00 & 0.00 & 0.00 & 15.38 & 100.00 \\
\hline 2 & 6.06 & 68.18 & 12.12 & 6.06 & 1.52 & 6.06 & 100.00 \\
\hline 3 & 0.00 & 12.77 & 57.45 & 14.89 & 4.26 & 10.64 & 100.00 \\
\hline 4 & 0.00 & 0.00 & 1.79 & 51.79 & 30.36 & 16.07 & 100.00 \\
\hline 5 & 0.00 & 0.00 & 0.00 & 3.33 & 15.00 & 81.67 & 100.00 \\
\hline \multicolumn{8}{|c|}{ Post-FDICIA, First Quartile State Income Growth } \\
\hline & & 2 & 3 & 4 & 5 & Absorption & Total \\
\hline 1 & 81.21 & 10.69 & 0.72 & 0.14 & 0.00 & 7.23 & 100.00 \\
\hline 2 & 10.78 & 74.57 & 3.36 & 0.61 & 0.20 & 10.48 & 100.00 \\
\hline 3 & 0.00 & 39.58 & 43.75 & 6.77 & 0.00 & 9.90 & 100.00 \\
\hline 4 & 0.00 & 6.42 & 31.19 & 40.37 & 12.84 & 9.17 & 100.00 \\
\hline 5 & 0.00 & 0.00 & 4.35 & 15.22 & 43.48 & 36.96 & 100.00 \\
\hline \multicolumn{8}{|c|}{ Pre-FDICIA, Second Quartile State Income Growth } \\
\hline & & 2 & 3 & 4 & 5 & Absorption & Total \\
\hline 1 & 78.57 & 14.29 & 0.00 & 0.00 & 0.00 & 7.14 & 100.00 \\
\hline 2 & 5.56 & 74.07 & 7.41 & 3.70 & 0.00 & 9.26 & 100.00 \\
\hline 3 & 0.00 & 3.45 & 58.62 & 13.79 & 6.90 & 17.24 & 100.00 \\
\hline 4 & 0.00 & 0.00 & 14.29 & 61.90 & 14.29 & 9.52 & 100.00 \\
\hline 5 & 0.00 & 0.00 & 2.94 & 11.76 & 17.65 & 67.65 & 100.00 \\
\hline \multicolumn{8}{|c|}{ Post-FDICIA, Second Quartile State Income Growth } \\
\hline & & 2 & 3 & 4 & 5 & Absorption & Total \\
\hline 1 & 76.46 & 11.33 & 0.53 & 0.18 & 0.00 & 11.50 & 100.00 \\
\hline 2 & 10.13 & 69.23 & 4.10 & 1.15 & 0.13 & 15.26 & 100.00 \\
\hline 3 & 0.00 & 46.53 & 31.94 & 6.94 & 1.39 & 13.19 & 100.00 \\
\hline 4 & 0.00 & 3.80 & 29.11 & 48.10 & 8.86 & 10.13 & 100.00 \\
\hline 5 & 0.00 & 0.00 & 2.13 & 14.89 & 36.17 & 46.81 & 100.00 \\
\hline
\end{tabular}


Table 12 (continued)

Transition Matrix for Large Institutions by Local Economic Conditions

This table provides the one-year transition matrix for composite examination ratings assigned in 1984 to 2003 to large FDIC-Insured institutions. The transition probabilities are expressed in percent. Large institutions are defined as those with at least \$250 million in total assets. The Pre-FDICIA period is defined as 1984 to 1991 and the post-FDICIA period is defined as 1992 to 2003. State income growth is the quarterly year-over-year growth in inflation adjusted personal

income in the state in which in the institution is headquartered. The growth rates are calculated over the 1984 to 2006 period and partitioned into quartiles. The first quartile of state personal income growth, representing the weakest growth, is the minimum to the $25^{\text {th }}$ percentile, the second quartile is the $25^{\text {th }}$ to the $50^{\text {th }}$, the third quartile is the $50^{\text {th }}$ to the $75^{\text {th }}$ percentile and the fourth quartile is the $75^{\text {th }}$ to the maximum, representing the strongest growth.

\begin{tabular}{|c|c|c|c|c|c|c|c|}
\hline \multicolumn{8}{|c|}{ Pre-FDICIA, Third Quartile State Income Growth } \\
\hline & & 2 & 3 & 4 & 5 & Absorption & Total \\
\hline 1 & 85.00 & 10.00 & 0.00 & 0.00 & 0.00 & 5.00 & 100.00 \\
\hline 2 & 7.50 & 77.50 & 5.00 & 0.83 & 0.00 & 9.17 & 100.00 \\
\hline 3 & 0.00 & 33.33 & 52.78 & 2.78 & 0.00 & 11.11 & 100.00 \\
\hline 4 & 0.00 & 3.85 & 19.23 & 57.69 & 11.54 & 7.69 & 100.00 \\
\hline 5 & 0.00 & 0.00 & 6.25 & 6.25 & 37.50 & 50.00 & 100.00 \\
\hline \multicolumn{8}{|c|}{ Post-FDICIA, Third Quartile State Income Growth } \\
\hline & & 2 & 3 & 4 & 5 & Absorption & Total \\
\hline 1 & 73.49 & 10.74 & 0.17 & 0.00 & 0.00 & 15.60 & 100.00 \\
\hline 2 & 13.04 & 66.91 & 2.15 & 0.57 & 0.00 & 17.34 & 100.00 \\
\hline 3 & 0.00 & 43.16 & 34.74 & 3.16 & 2.11 & 16.84 & 100.00 \\
\hline 4 & 0.00 & 5.41 & 29.73 & 48.65 & 2.70 & 13.51 & 100.00 \\
\hline 5 & 0.00 & 0.00 & 0.00 & 25.81 & 32.26 & 41.94 & 100.00 \\
\hline \multicolumn{8}{|c|}{ Pre-FDICIA, Fourth Quartile State Income Growth } \\
\hline & & 2 & 3 & 4 & 5 & Absorption & Total \\
\hline 1 & 76.19 & 19.05 & 0.00 & 0.00 & 0.00 & 4.76 & 100.00 \\
\hline 2 & 12.16 & 70.27 & 6.76 & 1.35 & 0.00 & 9.46 & 100.00 \\
\hline 3 & 0.00 & 27.59 & 55.17 & 10.34 & 0.00 & 6.90 & 100.00 \\
\hline 4 & 0.00 & 10.00 & 40.00 & 50.00 & 0.00 & 0.00 & 100.00 \\
\hline 5 & 0.00 & 0.00 & 7.14 & 14.29 & 57.14 & 21.43 & 100.00 \\
\hline \multicolumn{8}{|c|}{ Post-FDICIA, Fourth Quartile State Income Growth } \\
\hline & & 2 & 3 & 4 & 5 & Absorption & Total \\
\hline 1 & 69.91 & 10.63 & 0.15 & 0.00 & 0.00 & 19.31 & 100.00 \\
\hline 2 & 9.94 & 68.57 & 2.92 & 0.00 & 0.00 & 18.57 & 100.00 \\
\hline 3 & 0.00 & 42.11 & 35.09 & 5.26 & 0.00 & 17.54 & 100.00 \\
\hline 4 & 0.00 & 13.89 & 25.00 & 33.33 & 8.33 & 19.44 & 100.00 \\
\hline 5 & 0.00 & 0.00 & 0.00 & 30.00 & 20.00 & 50.00 & 100.00 \\
\hline
\end{tabular}


Table 13

Transition Matrix for Small Institutions by Local Economic Conditions

This table provides the 18-month transition matrix for composite examination ratings assigned in 1984 to 2003 to small FDIC-Insured institutions. The transition probabilities are expressed in percent. Small institutions are defined as those with less than \$250 million in total assets. The Pre-FDICIA period is defined as 1984 to 1991 and the post-FDICIA period is defined as 1992 to 2003. State income growth is the quarterly year-over-year growth in inflation adjusted personal income in the state in which in the institution is headquartered. The growth rates are calculated over the 1984 to 2006 period and partitioned into quartiles. The first quartile of state personal income growth, representing the weakest growth, is the minimum to the $25^{\text {th }}$ percentile, the second quartile is the $25^{\text {th }}$ to the $50^{\text {th }}$, the third quartile is the $50^{\text {th }}$ to the $75^{\text {th }}$ percentile and the fourth quartile is the $75^{\text {th }}$ to the maximum, representing the strongest growth.

\begin{tabular}{|c|c|c|c|c|c|c|c|}
\hline \multicolumn{8}{|c|}{ Pre-FDICIA, First Quartile State Income Growth } \\
\hline & & 2 & 3 & 4 & 5 & Absorption & Total \\
\hline 1 & 72.13 & 22.86 & 1.05 & 0.24 & 0.00 & 3.72 & 100.00 \\
\hline 2 & 9.26 & 73.31 & 10.23 & 2.91 & 0.59 & 3.70 & 100.00 \\
\hline 3 & 0.14 & 30.20 & 50.67 & 14.31 & 1.10 & 3.58 & 100.00 \\
\hline 4 & 0.00 & 4.68 & 24.27 & 50.85 & 13.26 & 6.93 & 100.00 \\
\hline 5 & 0.00 & 0.54 & 1.79 & 13.77 & 35.78 & 48.12 & 100.00 \\
\hline \multicolumn{8}{|c|}{ Post-FDICIA, First Quartile State Income Growth } \\
\hline & & 2 & 3 & 4 & 5 & Absorption & Total \\
\hline 1 & 78.02 & 16.41 & 0.61 & 0.09 & 0.06 & 4.80 & 100.00 \\
\hline 2 & 11.50 & 76.92 & 5.93 & 0.86 & 0.16 & 4.64 & 100.00 \\
\hline 3 & 0.28 & 45.29 & 42.55 & 7.53 & 0.45 & 3.90 & 100.00 \\
\hline 4 & 0.15 & 9.40 & 36.52 & 36.83 & 8.78 & 8.32 & 100.00 \\
\hline 5 & 0.55 & 3.28 & 8.20 & 21.86 & 24.59 & 41.53 & 100.00 \\
\hline \multicolumn{8}{|c|}{ Pre-FDICIA, Second Quartile State Income Growth } \\
\hline & & 2 & 3 & 4 & 5 & Absorption & Total \\
\hline 1 & 73.52 & 21.18 & 1.48 & 0.31 & 0.00 & 3.50 & 100.00 \\
\hline 2 & 9.05 & 75.03 & 9.45 & 2.03 & 0.30 & 4.13 & 100.00 \\
\hline 3 & 0.42 & 36.47 & 46.25 & 11.58 & 1.32 & 3.96 & 100.00 \\
\hline 4 & 0.00 & 5.47 & 27.86 & 48.65 & 11.78 & 6.24 & 100.00 \\
\hline 5 & 0.00 & 0.92 & 5.07 & 14.29 & 35.94 & 43.78 & 100.00 \\
\hline \multicolumn{8}{|c|}{ Post-FDICIA, Second Quartile State Income Growth } \\
\hline & & 2 & 3 & 4 & 5 & Absorption & Total \\
\hline 1 & 78.18 & 14.71 & 0.48 & 0.00 & 0.00 & 6.64 & 100.00 \\
\hline 2 & 12.76 & 75.84 & 4.79 & 0.74 & 0.03 & 5.84 & 100.00 \\
\hline 3 & 0.73 & 51.07 & 35.70 & 6.06 & 0.52 & 5.91 & 100.00 \\
\hline 4 & 0.00 & 16.37 & 37.83 & 31.09 & 5.50 & 9.22 & 100.00 \\
\hline 5 & 0.54 & 4.86 & 13.51 & 24.32 & 30.81 & 25.95 & 100.00 \\
\hline
\end{tabular}


Table 13 (continued)

Transition Matrix for Small Institutions by Local Economic Conditions

This table provides the 18-month transition matrix for composite examination ratings assigned in 1984 to 2003 to small FDIC-Insured institutions. The transition probabilities are expressed in percent. Large institutions are defined as those with less than \$250 million in total assets. The Pre-FDICIA period is defined as 1984 to 1991 and the post-FDICIA period is defined as 1992 to 2003. State income growth is the quarterly year-over-year growth in inflation adjusted personal income in the state in which in the institution is headquartered. The growth rates are calculated over the 1984 to 2006 period and partitioned into quartiles. The first quartile of state personal income growth, representing the weakest growth, is the minimum to the $25^{\text {th }}$ percentile, the second quartile is the $25^{\text {th }}$ to the $50^{\text {th }}$, the third quartile is the $50^{\text {th }}$ to the $75^{\text {th }}$ percentile and the fourth quartile is the $75^{\text {th }}$ to the maximum, representing the strongest growth.

\begin{tabular}{|c|c|c|c|c|c|c|c|}
\hline \multicolumn{8}{|c|}{ Pre-FDICIA, Third Quartile State Income Growth } \\
\hline & & 2 & 3 & 4 & 5 & Absorption & Total \\
\hline 1 & 74.80 & 19.36 & 0.92 & 0.10 & 0.00 & 4.82 & 100.00 \\
\hline 2 & 8.82 & 75.18 & 8.14 & 1.27 & 0.16 & 6.43 & 100.00 \\
\hline 3 & 0.20 & 39.95 & 44.44 & 10.22 & 0.95 & 4.23 & 100.00 \\
\hline 4 & 0.00 & 6.33 & 30.03 & 49.71 & 8.63 & 5.29 & 100.00 \\
\hline 5 & 0.00 & 1.28 & 5.98 & 15.81 & 35.47 & 41.45 & 100.00 \\
\hline \multicolumn{8}{|c|}{ Post-FDICIA, Third Quartile State Income Growth } \\
\hline & & 2 & 3 & 4 & 5 & Absorption & Total \\
\hline 1 & 77.99 & 14.84 & 0.33 & 0.00 & 0.02 & 6.82 & 100.00 \\
\hline 2 & 14.19 & 74.25 & 4.19 & 0.43 & 0.10 & 6.84 & 100.00 \\
\hline 3 & 0.81 & 52.79 & 36.86 & 3.95 & 0.29 & 5.29 & 100.00 \\
\hline 4 & 0.18 & 14.08 & 38.57 & 32.36 & 5.48 & 9.32 & 100.00 \\
\hline 5 & 1.74 & 7.83 & 11.30 & 26.09 & 20.00 & 33.04 & 100.00 \\
\hline \multicolumn{8}{|c|}{ Pre-FDICIA, Fourth Quartile State Income Growth } \\
\hline & & 2 & 3 & 4 & 5 & Absorption & Total \\
\hline 1 & 67.85 & 21.71 & 0.84 & 0.21 & 0.00 & 9.39 & 100.00 \\
\hline 2 & 8.47 & 74.06 & 7.59 & 2.14 & 0.29 & 7.44 & 100.00 \\
\hline 3 & 0.66 & 31.80 & 48.93 & 12.52 & 1.15 & 4.94 & 100.00 \\
\hline 4 & 0.00 & 5.44 & 24.09 & 46.89 & 13.73 & 9.84 & 100.00 \\
\hline 5 & 0.00 & 1.45 & 3.62 & 13.04 & 36.23 & 45.65 & 100.00 \\
\hline \multicolumn{8}{|c|}{ Post-FDICIA, Fourth Quartile State Income Growth } \\
\hline & & 2 & 3 & 4 & 5 & Absorption & Total \\
\hline 1 & 77.16 & 14.88 & 0.56 & 0.11 & 0.02 & 7.28 & 100.00 \\
\hline 2 & 13.32 & 75.78 & 4.04 & 0.59 & 0.06 & 6.20 & 100.00 \\
\hline 3 & 1.08 & 51.29 & 38.16 & 3.93 & 0.48 & 5.06 & 100.00 \\
\hline 4 & 0.00 & 18.94 & 45.17 & 24.04 & 4.37 & 7.47 & 100.00 \\
\hline 5 & 0.00 & 5.36 & 16.07 & 23.21 & 22.32 & 33.04 & 100.00 \\
\hline
\end{tabular}


Table 14

Transition Matrix for Large Institutions by Primary Federal Regulator

This table provides the one-year transition matrix for composite examination ratings assigned in 1984 to 2003 to large FDIC-Insured institutions by primary federal regulator. The transition probabilities are expressed in percent. Large institutions are defined as those with at least \$250 million in total assets. Absorption includes failures, mergers within a bank holding company, and mergers with a bank outside the holding company.

\begin{tabular}{|c|c|c|c|c|c|c|c|}
\hline \multicolumn{8}{|c|}{ FDIC } \\
\hline & 1 & 2 & 3 & 4 & 5 & Absorption & Total \\
\hline 1 & 79.16 & 9.93 & 0.08 & 0.00 & 0.00 & 10.84 & 100.00 \\
\hline 2 & 12.25 & 73.00 & 3.08 & 0.90 & 0.06 & 10.71 & 100.00 \\
\hline 3 & 0.00 & 38.93 & 42.14 & 6.79 & 2.14 & 10.00 & 100.00 \\
\hline 4 & 0.00 & 5.52 & 22.07 & 48.28 & 16.55 & 7.59 & 100.00 \\
\hline 5 & 0.00 & 0.00 & 3.53 & 12.94 & 34.12 & 49.41 & 100.00 \\
\hline \multicolumn{8}{|c|}{ Federal Reserve } \\
\hline & 1 & 2 & 3 & 4 & 5 & Absorption & Total \\
\hline 1 & 70.53 & 12.09 & 1.01 & 0.00 & 0.00 & 16.37 & 100.00 \\
\hline 2 & 10.60 & 71.57 & 4.58 & 0.48 & 0.00 & 12.77 & 100.00 \\
\hline 3 & 0.00 & 41.77 & 45.57 & 1.27 & 0.00 & 11.39 & 100.00 \\
\hline 4 & 0.00 & 0.00 & 30.00 & 60.00 & 5.00 & 5.00 & 100.00 \\
\hline 5 & 0.00 & 0.00 & 0.00 & 0.00 & 75.00 & 25.00 & 100.00 \\
\hline \multicolumn{8}{|c|}{ OCC } \\
\hline & 1 & 2 & 3 & 4 & 5 & Absorption & Total \\
\hline 1 & 77.05 & 11.77 & 0.30 & 0.00 & 0.00 & 10.88 & 100.00 \\
\hline 2 & 9.34 & 74.38 & 1.97 & 0.21 & 0.10 & 14.00 & 100.00 \\
\hline 3 & 0.00 & 42.37 & 37.29 & 11.86 & 3.39 & 5.08 & 100.00 \\
\hline 4 & 0.00 & 15.79 & 10.53 & 31.58 & 15.79 & 26.32 & 100.00 \\
\hline 5 & 0.00 & 0.00 & 0.00 & 6.67 & 13.33 & 80.00 & 100.00 \\
\hline \multicolumn{8}{|c|}{ OTS } \\
\hline & 1 & 2 & 3 & 4 & 5 & Absorption & Total \\
\hline 1 & 52.55 & 8.03 & 0.00 & 0.00 & 0.00 & 39.42 & 100.00 \\
\hline 2 & 8.06 & 51.64 & 2.99 & 0.30 & 0.00 & 37.01 & 100.00 \\
\hline 3 & 0.00 & 30.37 & 42.96 & 5.19 & 0.00 & 21.48 & 100.00 \\
\hline 4 & 0.00 & 0.79 & 26.98 & 51.59 & 9.52 & 11.11 & 100.00 \\
\hline 5 & 0.00 & 0.00 & 1.94 & 15.53 & 24.27 & 58.25 & 100.00 \\
\hline
\end{tabular}


Table 15

Kolmogorov-Smirnov Test Results

Transition Matrix for Large Institutions by Primary Federal Regulator

This table provides the results of Kolmogorov-Smirnov (K-S) tests applied to the one-year transition matrix for the

composite examination ratings assigned in 1984 to 2003 to large FDIC-Insured Institutions by primary federal regulator. Large institutions are those with at least \$250 million in total assets. The null hypothesis for the K-S test is that the row probabilities for the two groups are drawn from the same distribution. * ${ }^{*}=$ Can reject the null hypothesis at the $90 \%$ confidence level, $* *=95 \%$, $* * *=99 \%$

\begin{tabular}{|c|c|c|c|}
\hline \multicolumn{2}{|c|}{ FDIC vs. Federal Reserve } & \multicolumn{2}{|c|}{ OCC vs. FDIC } \\
\hline 1 & $* *$ & 1 & (None significant) \\
\hline 2 & & 2 & \\
\hline 3 & & 3 & \\
\hline 4 & & 4 & \\
\hline 5 & & 5 & \\
\hline \multicolumn{2}{|c|}{ OCC vs. Federal Reserve } & \multicolumn{2}{|c|}{ OCC vs. OTS } \\
\hline 1 & (None significant) & 1 & $* * *$ \\
\hline 2 & & 2 & $* * *$ \\
\hline 3 & & 3 & \\
\hline 4 & & 4 & \\
\hline 5 & & 5 & \\
\hline \multicolumn{2}{|c|}{ OTS vs. Federal Reserve } & \multicolumn{2}{|c|}{ OTS vs. FDIC } \\
\hline & $* * *$ & 1 & $* * *$ \\
\hline 2 & $* * *$ & 2 & $* * *$ \\
\hline 3 & & 3 & \\
\hline 4 & & 4 & \\
\hline 5 & & 5 & \\
\hline
\end{tabular}


Table 16

Transition Matrix for Small Institutions by Primary Federal Regulator

This table provides the 18-month transition matrix for composite examination ratings assigned in 1984 to 2003 to small FDIC-Insured institutions by primary federal regulator. The transition probabilities are expressed in percent. Small institutions are defined as those with less than \$250 million in total assets. Absorption includes failures, mergers within a bank holding company, and mergers with a bank outside the holding company

\begin{tabular}{|c|c|c|c|c|c|c|c|}
\hline \multicolumn{8}{|c|}{ FDIC } \\
\hline & 1 & 2 & 3 & 4 & 5 & Absorption & Total \\
\hline 1 & 77.99 & 16.21 & 0.53 & 0.08 & 0.01 & 5.19 & 100.00 \\
\hline 2 & 12.17 & 75.89 & 5.98 & 1.05 & 0.16 & 4.76 & 100.00 \\
\hline 3 & 0.38 & 43.03 & 43.17 & 9.19 & 0.80 & 3.42 & 100.00 \\
\hline 4 & 0.02 & 7.52 & 31.65 & 45.03 & 10.12 & 5.66 & 100.00 \\
\hline 5 & 0.15 & 2.25 & 5.77 & 18.28 & 35.21 & 38.35 & 100.00 \\
\hline \multicolumn{8}{|c|}{ Federal Reserve } \\
\hline & 1 & 2 & 3 & 4 & 5 & Absorption & Total \\
\hline 1 & 73.93 & 16.77 & 0.61 & 0.12 & 0.06 & 8.51 & 100.00 \\
\hline 2 & 11.68 & 76.19 & 5.10 & 0.51 & 0.10 & 6.42 & 100.00 \\
\hline 3 & 0.36 & 42.53 & 42.35 & 7.83 & 0.71 & 6.23 & 100.00 \\
\hline 4 & 0.00 & 4.23 & 31.69 & 42.25 & 12.32 & 9.51 & 100.00 \\
\hline 5 & 0.00 & 0.89 & 8.93 & 10.71 & 33.04 & 46.43 & 100.00 \\
\hline \multicolumn{8}{|c|}{ OCC } \\
\hline & 1 & 2 & 3 & 4 & 5 & Absorption & Total \\
\hline 1 & 74.93 & 13.61 & 0.79 & 0.05 & 0.00 & 10.61 & 100.00 \\
\hline 2 & 8.21 & 77.90 & 4.74 & 0.74 & 0.06 & 8.36 & 100.00 \\
\hline 3 & 0.21 & 40.81 & 44.15 & 6.16 & 0.94 & 7.72 & 100.00 \\
\hline 4 & 0.00 & 8.47 & 32.88 & 30.51 & 7.80 & 20.34 & 100.00 \\
\hline 5 & 0.00 & 0.00 & 7.14 & 11.90 & 27.78 & 53.17 & 100.00 \\
\hline \multicolumn{8}{|c|}{ OTS } \\
\hline & 1 & 2 & 3 & 4 & 5 & Absorption & Total \\
\hline 1 & 72.96 & 14.78 & 0.26 & 0.00 & 0.00 & 12.01 & 100.00 \\
\hline 2 & 12.41 & 73.53 & 5.44 & 0.58 & 0.08 & 7.97 & 100.00 \\
\hline 3 & 0.19 & 41.12 & 44.98 & 6.27 & 0.10 & 7.34 & 100.00 \\
\hline 4 & 0.17 & 10.45 & 32.93 & 40.94 & 6.62 & 8.89 & 100.00 \\
\hline 5 & 0.29 & 0.88 & 5.56 & 17.25 & 30.12 & 45.91 & 100.00 \\
\hline
\end{tabular}


Table 17

Kolmogorov-Smirnov Test Results

Transition Matrix for Small Institutions by Primary Federal Regulator

This table provides the results of Kolmogorov-Smirnov (K-S) tests applied to the 18-month transition matrix for the composite examination ratings assigned in 1984 to 2003 to small FDIC-Insured Institutions by primary federal regulator. Small institutions are those with at less than $\$ 250$ million in total assets. The null hypothesis for the K-S test is that the row probabilities for the two groups are drawn from the same distribution. $*=$ Can reject the null hypothesis at the $90 \%$ confidence level, $* *=95 \%, * * *=99 \%$

\begin{tabular}{|c|c|c|}
\hline FDIC vs. Federal Reserve & \multicolumn{2}{|c|}{ OCC vs. FDIC } \\
\hline $1 * *$ & 1 & $* * *$ \\
\hline 2 & 2 & $* * *$ \\
\hline 3 & 3 & $*$ \\
\hline 4 & 4 & $* * *$ \\
\hline 5 & 5 & $* *$ \\
\hline OCC vs. Federal Reserve & \multicolumn{2}{|c|}{ OCC vs. OTS } \\
\hline 1 & 1 & \\
\hline $2 * *$ & 2 & $* * *$ \\
\hline 3 & 3 & \\
\hline $4 *$ & 4 & $* * *$ \\
\hline 5 & 5 & \\
\hline OTS vs. Federal Reserve & \multicolumn{2}{|c|}{ OTS vs. FDIC } \\
\hline 1 (None significant) & 1 & $* * *$ \\
\hline 2 & 2 & $* *$ \\
\hline 3 & 3 & \\
\hline 4 & 4 & \\
\hline 5 & 5 & $*$ \\
\hline
\end{tabular}




\section{Table 18}

\section{Kolmogorov-Smirnov Test Results}

Transition Matrix for Small Institutions by Primary Federal Regulator, FDICIA and Business Cycle Periods This table provides the results of Kolmogorov-Smirnov (K-S) tests applied to the 18-month transition matrix for the composite examination ratings assigned in 1984 to 2003 to small FDIC-Insured Institutions by primary federal regulator, FDICIA periods and business cycle periods. Small institutions are those with at less than $\$ 250$ million in total assets. The pre-FDICIA period is defined as 1984 to 1991 . The post-FDICIA period is defined as 1992 to 2003. The business cycle periods are defined by the NBER business-cycle peaks and troughs. The null hypothesis for the K-S test is that the row probabilities for the two groups are drawn from the same distribution. ${ }^{*}=$ Can reject the null hypothesis at the $90 \%$ confidence level, $* *=95 \%$, ***=99\%

\begin{tabular}{|c|c|c|c|}
\hline \multicolumn{2}{|c|}{ FDIC } & \multicolumn{2}{|r|}{ Federal Reserve } \\
\hline Pre-FDICIA Expansion & S. Post-FDICIA Expansion & Pre-FDICIA Ex & pansion vs. Post-FDICIA Expansion \\
\hline 1 & $* * *$ & 1 & \\
\hline 2 & $* * *$ & 2 & $* * *$ \\
\hline 3 & $* * *$ & 3 & $* * *$ \\
\hline 4 & $* * *$ & 4 & $* * *$ \\
\hline 5 & $* * *$ & 5 & \\
\hline \multicolumn{2}{|c|}{ Pre-FDICIA Recession vs. Post-FDICIA Recession } & Pre-FDICIA R & cession vs. Post-FDICIA Recession \\
\hline 1 & $* * *$ & 1 & (None significant) \\
\hline 2 & $* * *$ & 2 & \\
\hline 3 & $* * *$ & 3 & \\
\hline 4 & $* * *$ & 4 & \\
\hline 5 & $* *$ & 5 & \\
\hline \multicolumn{2}{|c|}{ OCC } & \multicolumn{2}{|r|}{ OTS } \\
\hline \multicolumn{2}{|c|}{ Pre-FDICIA Expansion vs. Post-FDICIA Expansion } & \multirow{2}{*}{\multicolumn{2}{|c|}{$\begin{array}{l}\text { Pre-FDICIA Expansion vs. Post-FDICIA Expansion } \\
\qquad 1\end{array}$}} \\
\hline 1 & $* * *$ & & \\
\hline 2 & $* * *$ & 2 & $*$ \\
\hline 3 & $* * *$ & 3 & $* * *$ \\
\hline 4 & $* * *$ & 4 & $* * *$ \\
\hline 5 & $* * *$ & 5 & $* * *$ \\
\hline \multicolumn{2}{|c|}{ Pre-FDICIA Recession vs. Post-FDICIA Recession } & \multirow{2}{*}{\multicolumn{2}{|c|}{$\begin{array}{l}\text { Pre-FDICIA Recession vs. Post-FDICIA Recession } \\
\qquad 1 \quad \text { (None significant) }\end{array}$}} \\
\hline 1 & $* * *$ & & \\
\hline 2 & $* * *$ & 2 & \\
\hline 3 & $* * *$ & 3 & \\
\hline 4 & & 4 & \\
\hline 5 & & 5 & \\
\hline
\end{tabular}




\section{Table 19}

Transition Matrix for Large Institutions

This table provides the one-year transition matrix for composite examination ratings assigned in 1984 to 2003 to large FDIC-Insured institutions. The transition probabilities are expressed in percent. Large institutions are defined as those with at least \$250 million in total assets. The Pre-FDICIA period is defined as 1984 to 1991 and the postFDICIA period is defined as 1992 to 2003.

\begin{tabular}{|c|c|c|c|c|}
\hline \multicolumn{5}{|c|}{ Pre-FDICIA } \\
\hline & Upgrade & Stay the Same & Downgrade & Sample Size \\
\hline Upgrade & 20.00 & 65.00 & 15.00 & 20 \\
\hline Stay the Same & 13.82 & 74.80 & 11.38 & 123 \\
\hline Downgrade & 5.88 & 70.59 & 23.53 & 17 \\
\hline \multicolumn{5}{|c|}{ Post-FDICIA } \\
\hline & Upgrade & Stay the Same & Downgrade & Sample Size \\
\hline Upgrade & 9.95 & 77.73 & 12.32 & 211 \\
\hline Stay the Same & 11.25 & 82.56 & 6.19 & 1,244 \\
\hline Downgrade & 36.96 & 57.97 & 5.07 & 138 \\
\hline
\end{tabular}


Table 20

Transition Matrix for Small Institutions

This table provides the one-year transition matrix for composite examination ratings assigned in 1984 to 2003 to small FDIC-Insured institutions. The transition probabilities are expressed in percent. Small institutions are defined as those with less than $\$ 250$ million in total assets. The Pre-FDICIA period is defined as 1984 to 1991 and the postFDICIA period is defined as 1992 to 2003.

\begin{tabular}{ccccc}
\hline & \multicolumn{4}{c}{ Pre-FDICIA } \\
\hline Upgrade & Upgrade & Stay the Same & Downgrade & Sample Size \\
Stay the Same & 17.81 & 68.02 & 14.18 & 2,617 \\
Downgrade & 18.92 & 69.99 & 11.09 & 9,408 \\
\hline & 35.29 & 53.82 & 10.90 & 2,083 \\
\hline Upgrade & Ppgrade & Stay the Same & Downgrade & Sample Size \\
Stay the Same & 11.60 & 72.99 & 15.41 & 6,413 \\
Downgrade & 12.63 & 79.76 & 7.61 & 27,246 \\
\hline
\end{tabular}


Figure 1

Estimate of the Survival Functions

During Expansion Periods

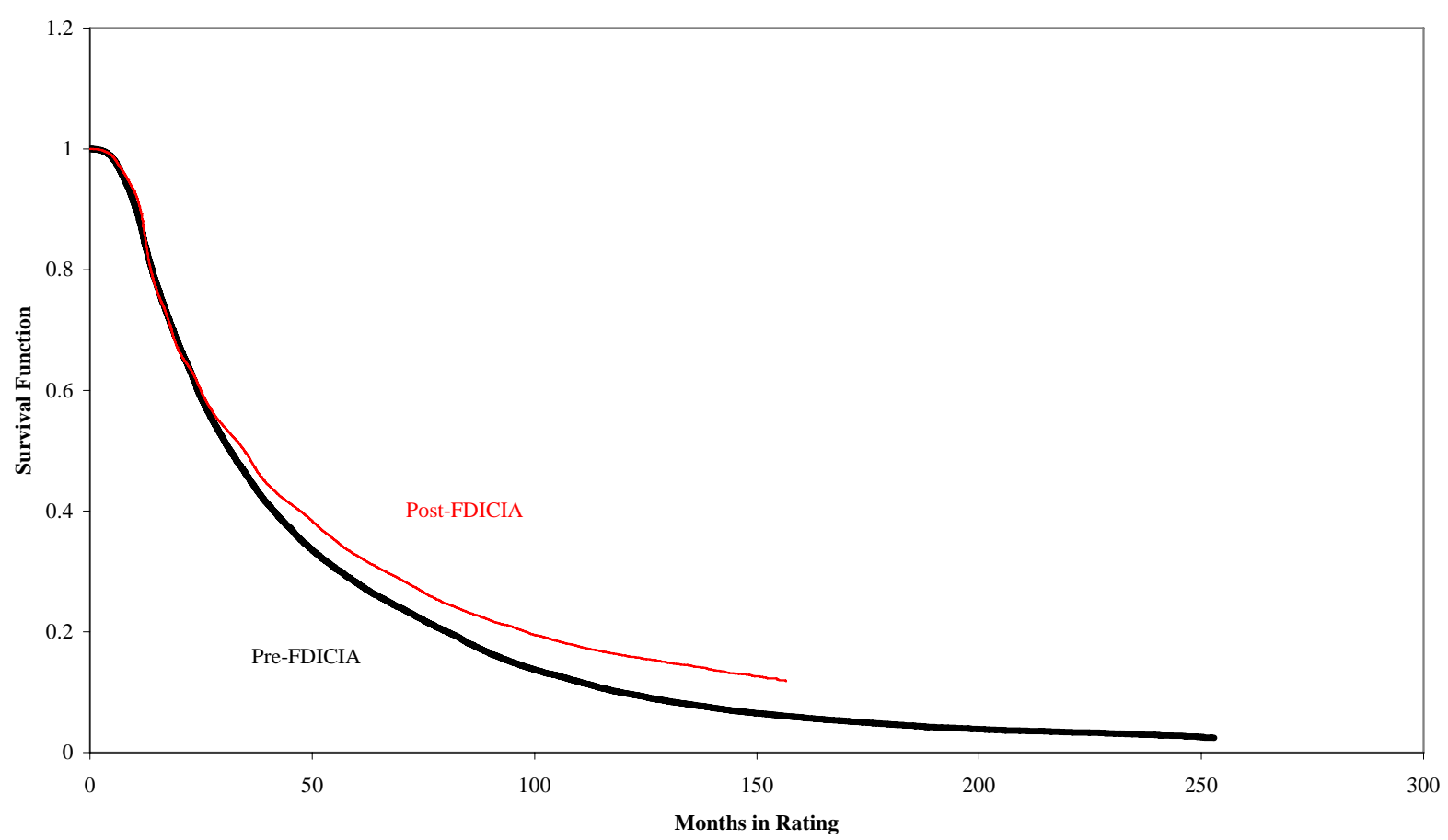

Figure 2

Estimate of the Survival Functions During Recession Periods

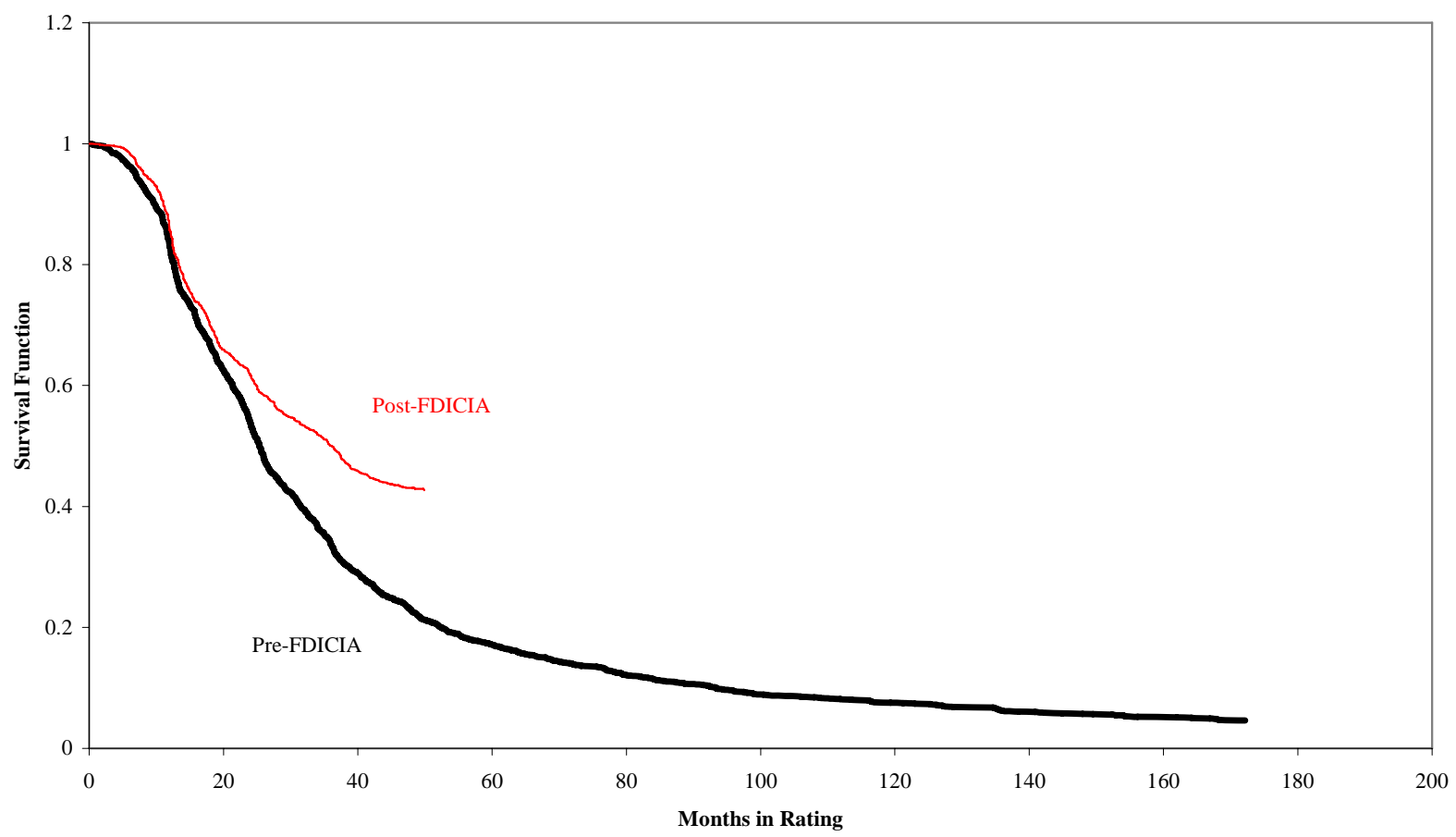


Figure 3

External Mergers

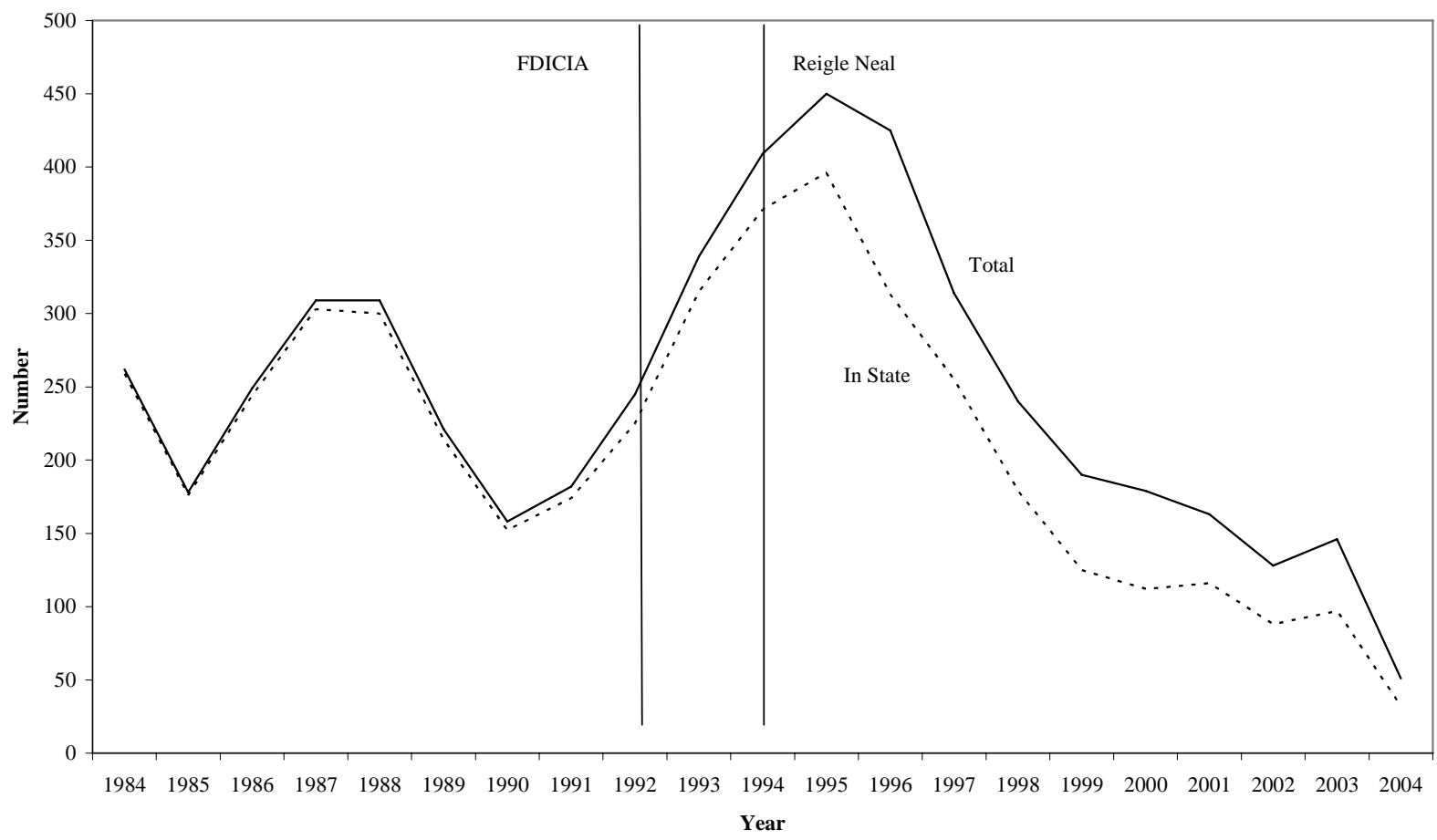

Figure 4

Roll-Ups

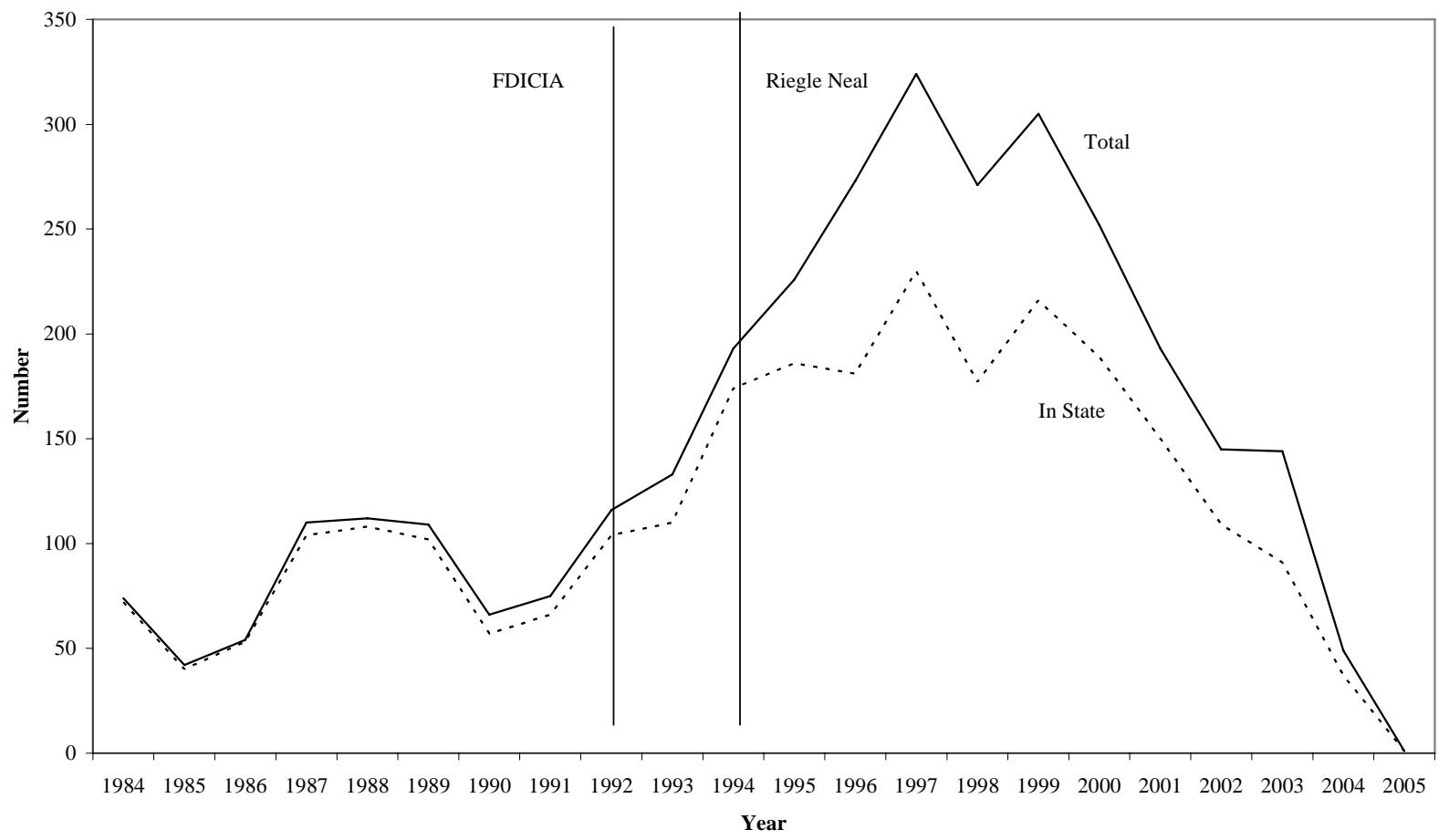

